\title{
Context, Timing and the Dynamics of Transitional Justice: A Historical Perspective
}

\author{
Laurel E. Fletcher* \& Harvey M. Weinstein ${ }^{* *}$ with Jamie \\ Rowen***
}

I. Introduction

A. Summary Status of Trials and Truth Commissions in Transitional Justice

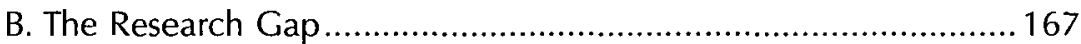

C. The Need to Reassess Transitional Justice ................................. 169

II. Methodology and History .......................................................... 170

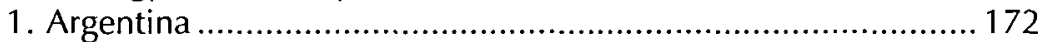

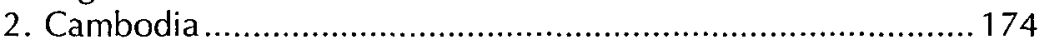

Authorship is alphabetical.

* Laurel Fletcher, J.D., is Clinical Professor of Law and Director, International Human Rights Law Clinic, University of California, Berkeley School of Law. Her work focuses on the areas of transitional justice and humanitarian law, human rights and anti-terrorism, as well as globalization and migration.

** Harvey M. Weinstein, M.D., M.PH is Senior Research Fellow at the Human Rights Center of the University of California, Berkeley and a Clinical Professor in the School of Public Health. He was Associate Director of the Human Rights Center from 1998-2005. Currently, he is Co-editor of the International Journal of Transitional Justice. His principal research interests are in transitional justice and social reconstruction, trauma and social repair, and in human rights and mass disaster.

*** Jamie Rowen is a J.D. candidate and Ph.D. student at Boalt Hall School of Law, University of California, Berkeley. She currently studies data analysis methods in transitional justice mechanisms and has worked with various human rights organizations in the Balkans, South Africa, Vietnam, and Costa Rica.

The authors wish to thank the following individuals for sharing their insightful comments on earlier drafts of this paper: Brandon Hamber, Timothy Kelsall, Louise Mallinder, Laurent Mayali, Naomi Roht-Arriaza, and Beth Van Schaack. We also benefited from presenting earlier versions of this paper at the Berlin 2007 International Conference on Law and Society; the IVR Congress of Philosophy of Law and Social Philosophy in Krakow, Poland; the 2008 International Studies Association Convention in San Francisco, California; and a faculty workshop at Berkeley Law School, University of California. 


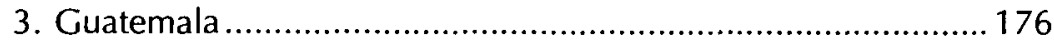

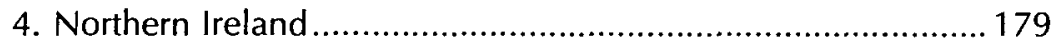

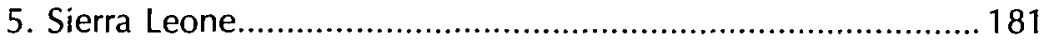

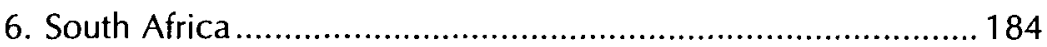

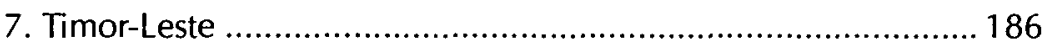

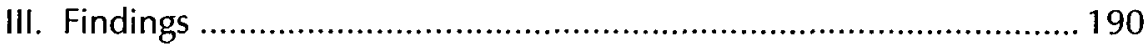

A. Strength and Legitimacy of Legal Institutions and Strength of Democracy.....

1. Countries with weak rule of law, low public confidence in the judicial system, and weak democracies....

2. Countries with strong rule of law, high public confidence in the judicial system, and stronger democracies

B. Rule of Law and Democracy and Transitional Justice Mechanisms

C. The Legacy of Colonialism.................................................... 195

D. Failed or Weak States .............................................................. 196

1. Strength of state and transitional justice mechanisms ............ 197

E. International (Multilateral) Intervention..................................... 198

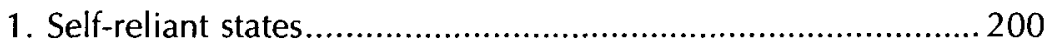

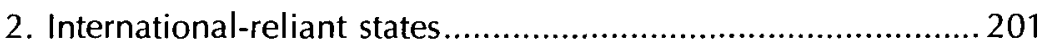

F. Government Commitment to Transitional Justice....................... 201

G. Post-transition Structural Reforms.............................................. 204

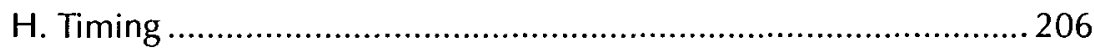

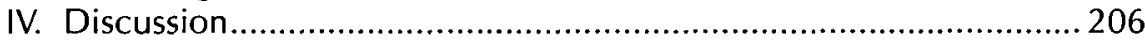

A. Contextual Dynamics of Transitional Justice .............................208

B. Capacity for Autonomous Resolution .......................................210

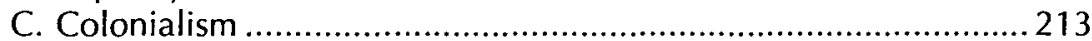

D. Transitional Justice Measures ................................................... 215

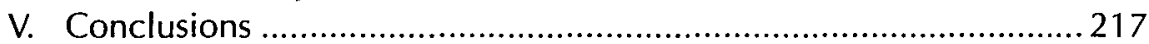

\begin{abstract}
Legal process is invoked by supporters of transitional justice as necessary if not a precondition for societies affected by mass violence to transition into a new period of peace and stability. In this paper, we question the presumption that trials and/or truth commissions should be an early response to initiating a transitional justice process. We conducted a multi-factorial, qualitative analysis of seven case studies in countries impacted by mass violence and repression-Argentina, Cambodia, Guatemala, Timor-Leste, Northern Ireland, Sierra Leone, and South Africa. What emerges is a fuller appreciation of the dynamic system in which transitional justice interventions occur. Each system component may influence the outcome of these interventions. We offer principles that can guide institutional development, scholarship, and policy prescriptions in the area of transitional justice.
\end{abstract}




\section{INTRODUCTION}

All transitional justice mechanisms-trials, truth commissions, vetting, reparations, memorialization, and institutional change-as well as other alternative interventions raise questions about truth, national identity, history, human rights, cultural practices, and good government. This article suggests that effective transitional justice is not solely a question of whether there should be a domestic or international trial, or a truth commission versus an international trial, or a cultural alternative as opposed to a traditional trial. The question is: what is most beneficial to the people whose lives have been disrupted or even destroyed by the perpetrators of violence?

Our inquiry to probe the evolved wisdom regarding transitional justice leads us to ask whether there are lessons that can be learned from a historical examination of the transitional justice processes that were put into place in a sample of several countries after their conflicts had ended. We are interested in seeing whether certain factors suggest that a particular kind of intervention is more appropriate or has greater impact on a society than another type of intervention. Further, we want to see whether there is an issue of timing or sequencing that might suggest that a particular form of transitional justice should be instituted first. We question whether the very term "transitional justice" may prove to be a misnomer, since what emerges from our investigation is an appreciation that we are looking at processes of transformation which may be jump started or supported by particular interventions. Finally, we are interested in determining how such measures interact with other societal changes to effect social reconstruction.

To gain insight into these presumptions, we examined several cases of countries impacted by mass violence. We looked at different regions, different ways in which the conflict concluded (military victory versus negotiated agreement), different underlying causes (ideological beliefs, ethnicity/ $\mathrm{racial} / \mathrm{religious} \mathrm{differences,} \mathrm{drives} \mathrm{for} \mathrm{independence,} \mathrm{separatism,} \mathrm{economic}$ disparity), and different responses to the violence (amnesties, national trials, international trials, hybrid courts, truth commissions, and international involvement). For each case, we looked at what has happened within each sector of the country-legal, political, social, and economic-since the formal end of the conflict to the present with special reference to context and tradition. We recognize that some of these categories and boundaries may be contested. However, we offer these as a first attempt to make some sense of the dynamic and often chaotic nature of post-conflict, societal reconstruction.

Thus, this analysis is primarily qualitative in nature; we are attuned to the themes that emerge when one reviews the unfolding of sectoral developments in a particular country after the close of cataclysmic violence. We have selected our case studies in order to examine several theoretical 
presumptions: (1) that transitional justice in developed countries may differ in important ways from that in less developed, (2) that the nature and length of the conflict and its termination vary and influence transitional justice mechanisms, (3) that cultures and traditions may be an important factor in how transitional justice develops, (4) that international intervention brings unexpected outside influences to bear on post-conflict policies; and (5) that adherence by a country to Western models of justice will influence the form that transitional justice takes and how it is perceived.

Our case studies suggest a need for new thinking about the relationship between transitional justice mechanisms and societal transitions. We hope that these findings will lead to principles that can guide institutional development, scholarship, and policy prescriptions in the area of transitional justice.

\section{A. Summary Status of Trials and Truth Commissions in Transitional Justice}

The creation of the ad hoc International Criminal Tribunal for the former Yugoslavia (ICTY) ushered in a new era in international law as well as international relations. Justice for mass violence-in the form of criminal accountability - has long been an elusive demand of many victims and human rights groups. With the creation of the International Criminal Court (ICC), this demand has moved squarely from a moral exhortation to a legal obligation owed by states party to the agreement to try those accountable for international crimes. However, much of the literature on transitional justice suggests or assumes that a legal response should be the primary measure by which progress toward rebuilding societies torn apart by communal violence should be judged. How else can we understand the lament that Slobodan Milosevic's death irreparably damaged-or at least indelibly marred-the prospects for the victims of the Balkans conflict to see justice and for Serbia to put to rest its role in the horrors?' ${ }^{1}$ This initial focus on trials leads us to question whether the emergence of criminal accountability for mass atrocities has dislodged or obscured the importance of other processes and interven-

1. The Serbian election in January 2007 gave the Serbian Radical Party (an ultra-nationalist party) the largest single bloc of seats and its leader, Tomaislav Nikolic, was elected speaker of Parliament on 8 May 2007. Less than one week later (14 May 2007), he was forced to step down when pro-European parties formed a coalition to lead the government. See Euractive.com, Ultras Win Serbian Election, 31 May 2007, available at http://www. euractiv.com/en/elctions/ultras-win-serbian-election/article-161062. See also Radio Free Europe/Radio Liberty, Former Milosevic Ally Elected Serbian Parliament Speaker, 8 May 2007, available at http://www.rferl.org/featuresarticle/2007/05/8f5d3da5-8dc8-4ab7a88d-eaf62c600088.html. 
tions needed to create an enduring platform for social stability in countries that have experienced protracted, state-sponsored violence. ${ }^{2}$

In the last decade, there has been broad recognition that multiple kinds of interventions and institutional changes are necessary for stability, but there remains an almost unremitting spotlight on trials and truth commissions. Not surprisingly then, truth commissions have taken on a life of their own. Despite the fact that it was not the first, the valorization of South Africa's Truth and Reconciliation Commission has breathed new life into truth-telling processes leading to such commissions in Sierra Leone, Liberia, and Timor-Leste. The impact of these truth commissions on the population of those who have suffered under mass violence remains to be seen. Early studies suggest that outcomes may not be clear cut. ${ }^{3}$ There is no established system of review, nor have there been any cross-country comparisons that make generalization suspect. However, historically and anecdotally, the truth commissions of Chile, Argentina, Brazil, and South Africa appear to have contributed in important ways to the stability that each of these states has achieved. Regardless, support for truth commissions is not universal, as resistance to the formation of such a commission in Bosnia and Herzegovina, the mixed reception of the Moroccan truth commission, ${ }^{4}$ and the variable success of previous commissions (such as Nigeria, Ethiopia, and Timor-Leste) demonstrate.

\section{B. The Research Gap}

Despite the expansion and acceptance of transitional justice mechanisms to respond to the repression and violence that are characteristic of intrastate conflict, the past fifteen years have not seen a concomitant surge of empirical research that would substantiate the direction that the international community has taken. David Mendeloff has offered a trenchant critique of truth-seeking, truth-telling, and post-conflict peace building that illustrates how flawed or contentious the claims are about the utility of truth commissions or other similar mechanisms. ${ }^{5}$ Jack Snyder and Leslie Vinjamuri echo

2. Laurel Fletcher \& Harvey M. Weinstein, Violence and Social Repair: Rethinking the Contribution of Justice to Reconciliation, 24 Hum. RTs. Q. 573 (2002).

3. James Gibson \& Heidi Macdonald, Truth-Yes, Reconciliation-Maybe: South Africans Judge the Truth and Reconciliation Process (2001), available at http://ijr.org.za/publications/archieve/ surveys; Rosalind Shaw, Rethinking Truth and Justice In Sierra Leone, United States InstituTE of PeACe SPECIAL RePORt 130 (Feb. 2005), available at http://www.usip.org/pubs/ specialreports/sr130.pdf; Tim Kelsall, Truth, Lies and Ritual: Preliminary Reflections on the Truth and Reconciliation in Sierra Leone, 27 Hum. RTs. Q. 361 (2005).

4. See Pierre Hazan, Morocco: Betting on a Truth and Reconciliation Commission, UNITED States Institute OF PeAce SpeCial Report 165 (July 2006), available at hittp://www.usip.org/ pubs/specialreports/sr165.pdf.

5. David Mendeloff, Truth-Seeking, Truth-Telling, and Postconflict Peacebuilding: Curb the Enthusiasm?, 6 INT'L STUd. Rev. 355 (2004). 
these concerns. ${ }^{6}$ Despite such criticisms, including our own, the juggernaut has continued. ${ }^{7}$

While scholars have used several research techniques to raise questions about the legitimacy of the assumptions made by advocates of transitional justice, the volume of such studies is low. However, the findings that have emerged raise critical questions for the field. For example, James Meernik examined whether the ICTY affected societal peace in Bosnia and Herzegovina by analyzing the impact of arrests and judgments on whether the different ethnic groups in the country cooperated or become more conflicted. ${ }^{8}$ Importantly, his data showed that there was generally little effect in any direction. ${ }^{9}$ James Gibson's elegant study of whether there was any relationship between the work of the South African truth commission and reconciliation offered a model of an empirical approach to assessing the effects of transitional justice strategies. ${ }^{10}$ While critiques have been offered about the methodology, variable definitions, and statistics in Gibson's work, ${ }^{11}$ there is no question that the approach is a milestone in testing widespread assumptions. There are limitations to these methods, but given the muddled nature of transitional justice, studies such as these are essential both to elucidate what these mechanisms do and whether they actually make a significant change on the ground. As of this writing, there is little empirical data to support the common assumptions that underlie the utility either of criminal trials for alleged perpetrators or truth and truth/reconciliation commissions.

Yet, as Alexander Wilde illustrated in his analysis of the post-Pinochet era in Chile, historical events in which repression, abuse of human rights, and mass violence occurred have a way of returning-often in disguised form-as "irruptions of memory." 12 He saw this as the "expressive dimension of transitional politics." ${ }^{13}$ His analysis suggested that there are limitations to

6. Jack Snyder \& Leslie Vinjamuri, Trials and Errors: Principle and Pragmatism in Strategies of International Justice, 28 INT'L SECURIT 5 (2003-04).

7. See Fletcher \& Weinstein, supra note 2.

8. James Meernik, Justice and Peace? How the International Criminal Tribunal Affects Societal Peace in Bosnia, 42 J. Peace Res. 271, 271-89 (2005).

9. Using the Kansas Event Data System of coded news stories, he found "little evidence to support the notion that the ICTY had a positive impact on societal peace . . . more often than not, ethnic groups responded with increased hostility toward one another after an arrest or judgment." Id.

10. James L. Gibson, Overcominc Apartheid: Can Truth Reconcile a Divided Nation? (2004).

11. David Backer, Book Review, 39 Comp. Pol. Stud. 1157 (2006) (reviewing J.L. Gibson, Overcominc Apartheid: Can Truth Reconclle A Divided Nation? (2005)).

12. Alexander Wilde, Irruptions of Memory: Expressive Politics in Chile's Transition to Democracy, 31 J. Latin Am. Stud. 473, 474 (1999).

13. Id. These incidents are the "public events that break in upon Chile's national consciousness, unbidden and often suddenly, to evoke associations with symbols, figures, causes, ways of life which to an unusual degree are associated with a political past that is still present in the lived experience of a major part of the population." Id. at 475 . 
our understanding of how states cope with their traumatic histories. Additionally, we have seen how, even after an extended period of time, there has been a resurgence of criminal justice for past crimes in Chile. An important question that cannot be addressed is whether there would have been any difference in the history of Chile if trials and the truth commission had occurred earlier. However, in Mozambique, where there was no transitional justice response as we currently define it, there has been little recurrence of violence or terror. Certainly, the claims by advocates that transitional justice responses lead to peace and reconciliation appear at this point to represent hopes for a happy ending and not evidence-based policies on which the international community can count. ${ }^{14}$

\section{The Need to Reassess Transitional Justice}

Taken as a whole, diplomats, policymakers, advocates, and scholars appear to be searching for a way to respond to the upsurge of mass violence that has swept across the developing countries, as well as the successor states of the Communist regimes in Eastern Europe, since 1989. ${ }^{15}$ Yet, the search for a response that can create a viable, stable, and democratic state remains elusive.

In part, the difficulty in rebuilding societies stems from the fact that conflict is a messy business and rebuilding efforts, despite uplifting rhetoric that often inaugurates such initiatives, are no less tidy. Each discipline searches, through its own distinctive lens, for parsimonious solutions to these complex problems. The results inevitably tend to exclude or diminish the relevance of factors that would be salient for another discipline. The challenge then is to attempt to make sense of societal changes. We acknowledge that our

14. See generally Fletcher \& Weinstein, supra note 2.

15. See Albert J. Jongman, The World Conflict and Human Rights Map 2000: Mapping Dimensions of Contemporary Conflicts and Human Rights Violations, Paper prepared for the 18th General IPRA Conference: Challenges for Peace Research in the 21 st Century, in Tampere, Finland (5-9 Aug. 2000), available at http://www.human.mie-u.ac.jp/ peace/18thpapers_index.htm. He notes:

The majority of 110 armed conflicts between 1989-1999 were internal, with most of the fatalities being civilians -84 percent according to one count. Of the 110 conflicts, 60 reached the level of war (1,000 battle-related deaths in a year) at some time during the period 1989-99. Only seven were inter-state wars. There were another ninety-four intrastate wars while the remaining nine cases were intrastate wars with foreign intervention. Some cases like Afghanistan, Sudan and Sri Lanka remained wars for all or most of the period.

These data emerge from: Peter Wallensteen \& Margareta Sollenberg, Armed Conflict, 1989-2000, 38 J. PEACE Res. 629 (2001). He notes further that a University of Hamburg research team lists 194 wars from 1945 to 1998 , with more than 90 percent of them in the developing countries. Jongman's paper offers extensive data on the various dimensions of political violence and armed conflict from the Interdisciplinary Research Programme on Causes of Human Rights Violations located in The Netherlands. 
analysis may be perceived as incomplete, partial, or even superficial by adherents of particular disciplines. However, what we have attempted here is an "ecological mapping" technique that tries to capture-albeit imperfectly-the dynamic interaction among factors that is lost or obscured by a discipline-specific approach to studying transitional justice.

In undertaking this project, we are responding to an approach among transitional justice advocates that appears to emphasize a standardized "tool kit" of interventions that can be applied in different contexts, such as trials, truth commissions, etc. The basic assumption is that the "tool kit" of interventions is appropriate and productive, if one can only determine which intervention to deploy. Our concern is that this approach relies on the assumption that immediate intervention is necessary-it is assumed that something will work-the trick is to find out what. We suggest that the appropriate sequencing is to first gain a comprehensive understanding of the local context and then to ask what, whether, and when transitional justice interventions should be initiated.

Finally, there is the question of what characterizes a successful outcome of a transitional justice intervention. We do not offer an answer to that question here. There is no consensus about the definition of success let alone criteria by which this can be measured. While these questions may prove impossible to answer, we believe that transitional justice scholars and proponents must continue to engage with these questions and avoid premature closure. In this paper, we offer a new approach to further thinking and research regarding the processes and outcomes of transitional justice.

\section{METHODOLOGY AND HISTORY}

We selected seven countries for study. The choice of post-conflict societies was dictated by the presumptions noted above. We also were interested in selecting as case examples countries that are representative of widely dispersed geographic areas. The seven states that we selected were divided on the basis of what most area experts would describe as the underlying primary and secondary causes of the conflict. ${ }^{16}$ The nature of individual conflicts will be discussed in more detail subsequently.

The countries that we looked at were:

16. See Ben Kiernan, How Pol Pot Came to Power: Colonialism, Nationalism and Communism in Cambodia 1930-1975 (2004); Don Greenless \& Robert Garran, Deliverance: The Inside Story of East Timor's Fight for Freedom (2002); Leonard Monteath Thompson, A History of South Africa (Yale University Press 3d ed. 2001) (1969); Palil Chevigny, Edge of the Knife: Police Violence in the Americas (1995); Joseph Ruane \& Judith Todd, The Dynamics of Conflict in Northern Ireland: Power, Conflict and Emancipation (1996). 


$\begin{array}{ll}\begin{array}{ll}\text { Argentina } \\ \text { Cambodia }\end{array} & \begin{array}{l}\text { ideological } \\ \text { ideological } \\ \text { Guatemala }\end{array} \\ \begin{array}{l}\text { ideological/identity-based } \\ \text { identity-based }\end{array} \\ \text { Sierra Leone } & \begin{array}{l}\text { socioeconomic } \\ \text { South Africa }\end{array} \\ \text { identity-based, economic } \\ \text { Timor-Leste } & \text { independence, identity-based }\end{array}$

Two countries among our case studies are well-developed in terms of political and economic infrastructure (Argentina, Northern Ireland); three are lesser developed states (Guatemala, Sierra Leone, and Cambodia); South Africa is well-developed with respect to infrastructure and industry, but the majority of the population lives in an underdeveloped country, and one is a new country (Timor-Leste) that also is less developed. We selected case studies to achieve regional diversity - two countries from Latin America, two from Asia, two from Africa, and one from Europe. In this way, we hope to explore some of the dimensions of cultural difference with the caveat that the cases selected may not be emblematic of the entire region.

We examined the histories of these states giving special attention to the nature of conflict, historical culture, strength of Western legal tradition, length of conflict and period of time since conflict terminated, presence or absence of international intervention, political commitment to addressing the past, and finally, the type of transitional justice mechanism that was implemented-truth commission or truth and reconciliation commission, amnesties, or domestic trials. We also separately examined and plotted the key legal, political, social, and economic events since the end of the conflict. From this process, we identified several factors that appear to be

17. We note that there are differing perspectives on the vocabulary to describe the territory, in this article we refer to the region by its official designation, Northern Ireland.

18. In using these terms, we mean the following: ideological refers to those conflicts in which the underlying conceptual vision of what the struggle is designed to achieve drives the warring parties. Examples might be the Marxist view of the Sendero Luminoso in Peru or the Islamist drive of Al Qaeda. Independence and separatist movements are ideologically driven but focus on achieving separation and autonomy from another power (internal or external). Identity-based conflicts have their roots in perceived differences between or among groups whose members see themselves as similar and who see the other group(s) as holding different ideas and values from their group. Identity-based conflicts arise often when one group desires hegemony or when a group feels that its existence is threatened by the goals of another. Identity-based conflicts arise from longheld negative stereotypes that become exaggerated in order to dehumanize the "other." Socioeconomic factors drive conflict when a population group is disenfranchised with limited access to opportunities for education, employment, wealth, and voice. This limitation in access is usually perceived as an inequity derived from the policies of a population group that controls wealth or government. We recognize that ideological, identity-based, and economic causes frequently become intertwined as the dominant group justifies its dominance on the basis of identity and exploits the socio-economic system to maintain its hegemony. 
important in determining the choice and implementation of transitional justice measures. An analysis of these factors suggests certain patterns that, in turn, have an impact on the interventions. A pattern was delineated when it appeared across countries although it might be expressed uniquely in a particular state. We do not suggest that these are the only factors of importance, but they do suggest regularities that may indicate how and when we might consider specific transitional justice interventions.

For the reader's benefit, included below are brief summaries of the history of the seven case studies. The summaries focus on the eight key factors that arose from our intensive investigation into the events, chronologies, and contexts of violence and transition.

\section{Argentina}

While the history of Argentina is filled with the problems of militarism, dictatorship, economic failure, and social instability, the country as a whole has not had a history of basic insecurity. Its economic institutions have worked reasonably well, and much of the time, government structures have been accountable to the people.

In 1976, military officers seized power in a coup. Argentina's resulting "Dirty War" is thought to have resulted in at least 30,000 deaths. ${ }^{19}$ The underlying causes were political: deep class divisions accompanied a politically polarized climate in which far right and far left groups engaged in terrorist attacks on civilians. ${ }^{20}$ Yet even during this period the courts played an important role; families of the disappeared appealed to the judicial system, filing writs of habeas corpus to find their loved ones. ${ }^{21}$

After the return to democracy, reforms to strengthen the rule of law, non-violent protest, and the reduction of social stratification addressed the underlying factors that contributed to the social breakdown. ${ }^{22}$ Early in the

19. Argentina marks coup anniversary, BBC News, 24 Mar. 2006, available at http://news. bbc.co.uk/2/hi/americas/4839896.stm.

20. The historic distrust of popular rule in favor of military intervention to restore public order in times of political crisis also set the stage for the military coup and dictatorship. THE Legacy of Human Rights in the Southern Cone: Argentina, Chile and Urucuay (Luis Roniger ed., 1999); Horacio Verbitsky, The Flight: Confessions of an Argentine Dirty Warrior (Ester Allen trans., 1996).

21. While the courts were non-responsive and politically compromised with respect to reigning in the abuses of the dictatorship, they were often effective in other areas of dispute resolution.

22. Reviewing major political developments since 1983, we see that civil society indeed has played a vocal and critical role in promoting human rights and rule of law. Victims, their families, and supporters continue to publicize abuses that occurred during the dictatorship and to advocate for accountability for military perpetrators in domestic and international venues-legal as well as political. Civil groups also defeated proposed censorship laws in 1995, and accountability for police brutal- 
transition to democracy in Argentina, the power of the military greatly influenced the pace and nature of this transition. Initial trials of some of the top junta generals led to mounting pressure by the military against criminal prosecutions. Additionally, in 1986 and 1987, the legislature passed amnesty laws that effectively halted criminal prosecutions for the next eighteen years. ${ }^{23}$ However, in 1991, the legislature created a compensation scheme for those jailed by the government during the dictatorship and by 1993 almost half of the 8,300 claims had been processed. The government extended the reparations program in 1994 to include compensation to families of those who disappeared..$^{24}$

Despite periodic and deep financial crises-in 1989-1992 and again in late 2000 , which reduced many middle class families to the point of poverty and brought large-scale civil protests-the military has not disrupted the constitutional order of the government since the transition. ${ }^{25}$ The pace of accountability picked up speed again in 2003, after the election of left-ofcenter President Nestor Kirchner. ${ }^{26}$

ity assumed a high visibility in the mid 1990s. In 1993, the Secretary for Security established procedures to purge the police force of members who have abused their authority and forced the separation of approximately 1,000 members from the force. Labor law reform in 1998, increased the bargaining power of unions and established alternative dispute resolution mechanisms to resolve labor disputes. See generally U.S. Dep't of State, 1999 Country Reports on Human Rights Practices: Argentina (1999).

23. After the amnesty laws were enacted, progress toward accountability-even if only symbolic - largely took place during the tenure of presidents who supported accountability for past crimes. For example, in 1989, the conservative candidate President Carlos Menem was elected and declared a general pardon for military leaders. Reelected in 1995, Menem's progress to confront the past was minimal; his interior minister released additional names of individuals disappeared by the junta during the dictatorship. For a history of presidential policies regarding transitional justice in Argentina, see THE LEGACr of Human Rights in the Southern Cone, supra note 20.

24. The 1994 law corrected the problem excluding those disappeared by the state from eligibility to receive reparations under the 1991 statute. National court decisions had awarded large sums-ranging from $\$ 250,000$ to $\$ 3$ million-to families of the disappeared, spurring the Argentine Congress to pass a new law to extend reparations to those who were killed and disappeared. Again, in 1998, the government committed to spending up to $\$ 3$ billion to cover projected costs of reparations, including a program to assist a victims' group, the Grandmothers of the Plaza de Mayo, to investigate and recover children of victims who the military took into or were born in custody and placed with military families. Law No. 24,411, 28 Dec. 1994, B.O.; Law No. 24,321, 8 June 1994, B.O. See also Priscilla Hayner, Unspeakable Truths: Confronting State Terror and Atrocity 176-77, 317 (2001). The CEH also recommended reparations in its report. See Historical Clarification Commission, Guatemala: Memory of Silence, Conclusions: The Tragedy of Armed Confrontation, available at http://shr.aaas.org/guatamala/ceh/report/ english/conc1.html.

25. However, throughout the post-transition period, police misconduct, overcrowded prisons and mistreatment of prisoners, and anemic economic growth and economic disparities persisted as indicators that government transparency and accountability measures should be further strengthened.

26. In contrast to President Menem's opposition to judicial action in Spain against Argentine military officials accused of crimes, Kirchner supported extraterritorial judicial action 
Victims' families have persisted in their demands for criminal accountability against the military officers responsible for crimes committed during the dictatorship. ${ }^{27}$ Recently, intensive lobbying by these victims and other civil society groups within Argentina have successfully overturned amnesties and revived criminal prosecutions for human rights violations during the Dirty War.

\section{Cambodia}

Scarred by a massive US bombing campaign and other fallout from the Vietnam War and the Cold War, the Khmer Rouge took power in Cambodia in 1975. During its four years in power, the Khmer Rouge attempted to revert back to an agrarian culture. Dissidents, the educated, professionals, and religious minorities were viciously persecuted. In this four-year period alone, the Khmer Rouge are thought to be responsible for between 1.5 and 2 million deaths. ${ }^{28}$ While Khmer Rouge rule was ended by a Vietnamese invasion in 1979 , and a Vietnamese backed domestic government was established, the Khmer Rouge leadership did not fully surrender until 1999.29

The United Nations, after years of a hands-off approach, established the United Nations Transitional Authority in Cambodia in 1991 to prepare for a transfer of power to Cambodians under a new constitution. The 1993 internationally-supervised election saw the formation of a new government and the withdrawal of the UN mission.

The international community actively involved itself in pressing the government of Cambodia to implement transitional justice measures. Despite discussion of a war crimes tribunal during the 1980s, and the post-Khmer

against the accused. He also announced the creation of a museum at the site of a former torture center to honor the memory of the victims, signaling public repudiation of the status traditionally enjoyed by the military and solidarity with those terrorized under the regime. U.S. Dep't of State, 2004 Country Reports on Human Rights Practices: Argentina (2004).

27. See U.S. Dep't of State, 2006 Country Reports on Human Rights Practices: Argentina, (2006).

28. Tom Fawthrop \& Helen Jarvis, Geming Away with Genocide? Elusive Justice and the Khmer Rouge Tribunal 3-4 (2004).

29. Kiernan eloquently states: "In the thirty years after World War II, Cambodia witnessed the reassertion of colonial power, the spread of nationalism, the birth and growth of a communist party, the achievement of independence, the stifling of reform after a decade of peace, the rise of an armed domestic insurgency, the encroachment of an international war, massive bombardment and civilian casualties, pogroms and ethnic 'cleansing' of religious minorities. From 1975 to 1979 , genocide took another 1.7 million lives. Then, after liberation from the Khmer Rouge regime [and the formation of the State of Cambodia in 1989], Cambodia survived a decade of foreign occupation, international isolation, and guerilla terror and harassment. UN intervention and democratic transition were followed by Cambodia's defeat of the Khmer Rouge in 1999 amid continuing internal tension and political confrontation." Ben Kiernan, Introduction: Conflict in Cambodia, 1945-2002, 34 Critical Asian Stud. 483, 492-93 (2002). 
Rouge government's trial of Khmer Rouge leaders in absentia, it was not until 1998, after the leaders of Cambodia made a formal request for a judicial intervention, that the United Nations Secretary General formed a Commission of Experts to analyze the need for a tribunal. ${ }^{30}$ In 1999, this group released a report that recommended an international tribunal, similar to that of the ICTY and ICTR, to try the Khmer Rouge for genocide under the Genocide Convention. Insistence by Cambodia that the tribunal be a domestic court with minimal international involvement led to protracted negotiations. ${ }^{31}$ Finally, in 2003, an agreement was reached that allowed the formation of the Extraordinary Chambers in the Courts of Cambodia (ECCC). ${ }^{32}$

The Cambodian court system itself is based on the colonial French, dual court model. The Vietnamese, after defeating the Khmer Rouge, imposed a Communist system where the law served the state. ${ }^{33}$ This, combined with traditional deference to Monarchal power, has hindered the development of an independent juridical force. ${ }^{34}$

Political support for transitional justice has been intermittent and thin. As of this writing, the Cambodian government had not proposed any other transitional justice measures aside from prosecutions by the tribunal. ${ }^{35}$ It remains to be seen whether the tribunal will enjoy popular support and be viewed as a legitimate process to adjudicate crimes committed more than

30. This is widely considered to be the first attempt at legitimate prosecutions. After the Vietnamese invasion of 1979 , the new government initiated what was widely condemned as a show trial of former Khmer Rouge leaders Pol Pot and leng Sary. Theresa Klosterman, The Feasibility and Propriety of a Truth Commission in Cambodia: Too Little? Too Late?, 15 ARIz. J. INI'L \& COMP. L. 833, 853-54 (1998). In 1997, Pol Pot's own forces conducted a second trial which also was widely condemned. Id.; see also Michael Vickery \& Naomi Roht-Arriaza, Human Rights in Cambodia, in Impunity and Human Rights in InTERnational Law and Practice 243 (Naomi Roht-Arriaza ed., 1995).

31. Susan E. Cook, Prosecuting Genocide in Cambodia: The Winding Path Towards Justice, MAGAZINE: The TRIBUNALS, May 2001, available at http://www.crimesofwar.org/tribun-mag/ mag_cambodia.html.

32. The court is composed of a mix of local and international personnel with co-prosecutors, co-investigating judges, a majority of Cambodian judges and a "supermajority" decisionmaking mechanism. Craig Etcheson, A "Fair and Public Trial": A Political History of the Extraordinary Chambers, Open Society Justice Initiative (Apr. 2006), available at http:// www.justiceinitiative.org/db/resource2?res_id=103182. The agreement establishing the ECCC prohibits the government of Cambodia from seeking amnesties or pardons and the court has the authority to review the prior amnesties or pardons that have been granted. Law to Amend the Law on the Establishment of the Extraordinary Chambers in the Courts of Cambodia for the Prosecution of Crimes Committed during the Period of Democratic Kampuchea, 27 Oct. 2004, Art. 40, available at http://www.cambodia.gov. kh/krt/english/law\%20on\%20establishment.htm.

33. David P. Chandier, A History of Cambodia 228-35 (2000).

34. Dolores Donovan, Codification in Developing Nations: Ritual and Symbol in Cambodia and Indonesia, 31 U.C. Davis L. Rev. 693 (1998).

35. See Katheryn M. Klein, Bringing the Khmer Rouge to Justice: The Challenges and Risks Facing the Joint Tribunal in Cambodia, 4 Nw. J. INT'L HUM. RTs. 549 (2006). 
30 years ago. A prominent human rights organization suggests that the court suffers from a lack of authority, resources, and government support. ${ }^{36}$

The death of Pol Pot and the surrender of the remaining Khmer Rouge leadership in 1999 have extinguished the ideological battle that fueled the genocide in Cambodia. The persistence of extreme poverty, the concentration of economic power in the hands of an elite class, and the distortion of the rule of law and state authority through corruption indicate endemic structural inequities that may threaten political stability in the future. There have been few efforts by the state to address these systemic vulnerabilities and much of what the government has attempted is problematic. ${ }^{37}$ Little progress has been made to address these fundamental fissures that threaten stability.

\section{Guatemala}

In Guatemala, colonialism has left a legacy of racial discrimination that underlies the country's history of violence. Ladinos (mixed descendants of Spanish colonists and indigenous people) make up 40 percent of the population and have held power since colonial times. This elite group has subjected the indigenous population to legal, political, social, and economic discrimination. The disproportionate death toll among indigenous people during the years of war attests to the racial substrate that fuelled the conflict. ${ }^{38}$

For more than forty years, Guatemala suffered from civil war, coups, and human rights abuses. In 1994, the United Nations intervened and facilitated negotiations between the government and the Guatemalan National Revolutionary Unity (URNG) rebel group. As part of the peace accord, the parties agreed to international verification of terms of the agreement and established the United Nations Mission to Guatemala (MINUGUA). MINUGUA monitored the implementation of the process until August 2004. National and municipal elections followed, sponsored again by the United Nations, and in December 1996, the Peace Accords were signed. The ac-

36. See Human Rights Watch, Cambodia Government Interferes in Khmer Rouge Tribunal, Human Rights News (Dec. 2006), available at http://hrw.org/english/docs/2006/12/05/ cambod1 4752.htm.

37. In 2002, Presidents Sihanouk and Hun Sen overruled a judicial decision in a land dispute to award possession to hill tribes unlawfully evicted. It is not clear if this exercise of executive power violated the constitution and points to weakness of the judicial branch. Hun Sen's law reform policy announced in 2004 aimed at redistributing land to the poor but was unsuccessful and led to increases in forced evictions and displacement of the rural peasants by speculators. U.S. Dep't of State, 2004 Country Reports on Human Rights Practices: Cambodia (2004).

38. Mireya Navarro, Guatemalan Army Waged "Genocide," New Report Finds, N.Y. Times, 26 Feb. 1999, at A1. 
cords paid specific attention to human rights and called for the creation of a truth commission. ${ }^{39}$

The truth commission, or Historical Clarification Commission (CEH), was established on 23 June 1994. The $\mathrm{CEH}$, although independent, received financial support from a variety of international entities. ${ }^{40}$ The United $\mathrm{Na}$ tions played a significant role in the Commission's formation and operation by providing on-going support. In February 1999, the Commission released its final report titled, "Guatemala: Memory of Silence." The report clarified acts of genocide, apportioned responsibility, and noted the participation of the US government. Unfortunately, the report was not distributed widely and scholars suggest that the truth commission had little effect on the lives of ordinary citizens. ${ }^{41}$ In addition, the government did not fully implement the recommendations of the commission..$^{42}$

Since the Peace Accords concluded the Guatemalan civil war in 1996, various conservative political parties have controlled the government. Corruption and violence are rampant and progress toward meaningful legal and political reform has been minimal. Although legislation subsequent to the Peace Accords modified the amnesty law that immunized military leaders for criminal acts during the conflict, only a modest number of officials have been tried and convicted. ${ }^{43}$ Eight years after the signing of the Peace Accords, the

39. In 1995, prior to the accords, the Roman Catholic Church led by Bishop Gerardi founded the Archdiocese Office of Human Rights and began the Recovery of Historical Memory Project (REHMI). REHMI published its report in 1998 and two days later, Bishop Gerardi was murdered.

40. The Commission consisted of three members: Christian Tomuschat, a German professor and human rights expert, Otilia Lux de Coti, an indigenous Guatemalan education expert, and Alfredo Balsells Tojo, a Guatemalan lawyer. Guatemala: Memory Of Silence, Report Of The Commission For Historical Clarification, Conclusions And Recommendations (1998); Christian Tomuschat, Between National and International Law: Guatemala's Historical Clarification Commission, in Liber Amicorum Günter Jaenicke 991 (Volkmar Götz et al. eds., 1998)

41. See Francisco Goldman, Op-Ed., In Guatemala, All is Forgotten, N.Y. TImes, 23 Dec. 1996 , at A15; United Nations Verification Mission in Guatemala, Third Report, A/55/174 (July 2000) [hereinafter Guatemala Verification Report]. As the Commission was the product of a political compromise, its mandate was limited. The military supported the Commission in part because it lacked binding judicial power and would not name specific wrongdoers. Andrew N. Keller, To Name or Not To Name? The Commission for Historical Clarification in Guatemala, Its Mandate, and the Decision Not to Identify Individual Perpetrators 13 FLA. J. INT'L L. 289, 298-99 (2001). See also HaYner, supra note 24; Mark Freeman, Truth Commissions and Procedural. Fairness (2006).

42. Joanna R. Quinn \& Mark Freeman, Lessons Learned: Practical Lessons Gleaned from Inside the Truth Commissions of Guatemala and South Africa, 25 Hum. Ris. Q. 1117, 1123 (2003); Laura Arriaza \& Naomi Roht-Arriaza, Social Reconstruction as a Local Process, 2 Int'L J. Transitional Just. 152, 153-54 (2008).

43. None of the intellectual authors of the repression have been indicted, see Guatemala Verification Report, supra note 41 , although both domestic and foreign complaints have been filed. Nobel Peace Prize winner Rigoberta Menchú filed suit in December 1999 against high-ranking Guatemalan military and former civilian leaders in a Spanish court under the principle of universal jurisdiction for international crimes committed against 
government created an Anti-Racism Commission to support indigenous rights. More recently, President Oscar Berger has instituted reforms that dismantle some of the state institutions that planned and organized the violence. ${ }^{44}$ In addition, Berger created a reparations program for victims of the civil war. Victims' groups criticized the program as too modest and there have been persistent allegations of misdirection of its funds. The program is symbolically important; however, its poor implementation has raised questions about the government's commitment to addressing the dignity of the victims. ${ }^{45}$

Nevertheless, the government has instituted some reforms. In 2002, the government passed new laws to increase representation of indigenous and other marginalized groups in government. ${ }^{46}$ Recently, the government invigorated its commitment to implement the Peace Accords. The President's appointment of Nobel Peace Prize winner Rigoberta Menchú to oversee government compliance with the Peace Accords should keep the issue in the spotlight.

Mayans during the civil war. After an initial dismissal by lower courts, the Spanish Constitutional Tribunal reinstated the case in September 2005. Guatemala Genocide Case, 42 I.L.M. 686 (2003); see also Daniel Bodansky \& Naomi Roht-Arriaza, Guatemala Genocide Case: Spanish Constitutional Tribunal Decision on Universal Jurisdiction over Genocide Claims, 100 Am. J. INT. L. 207 (2006). In July 2006, a Spanish judge issued international arrest warrants for several Guatemalan former presidents, including Efrain Rios Mott for alleged international crimes committed during the conflict. The Guatemalan Supreme Court ordered the arrest of those named in the warrant, except Rios Mott. There are several domestic cases also pending. See generally El Centro Para La Accion Legal en Derechos Humanos, available at http://www.caldh.org/4_2A1dejure.html.

44. In 2003, conservative candidate Oscar Berger won the presidency. During his first year in office, President Berger dismantled the Presidential General Staff-the executive unit responsible for assassinations during the conflict. He also implemented the Commission for the Investigation of Illegal Bodies and Clandestine Security Apparatus (CICIACS, Comisión para la Investigación de Cuerpos llegales y Aparatos Clandestinos de Seguridad), an effort forged by the local and international human rights community and brokered by the United Nations. See Human Rights First, International Commission Against Impunity, available at http://www.humanrightsfirst.org/defenders/hrd_guatemala/ hrd_cicig.asp.

45. Guatemala Human Rights Commission/USA, Updates, Vol. 16, no. 7 (15 Apr. 2005); Susan Rose-Ackerman, Corruption and Post-Conflict Peacebuilding, 34 OHo N.U. L. Rev, 405, 417-18 (2008).

46. During the same year, the legislature decentralized economic planning mechanisms that enabled representatives of indigenous groups to sit on Departmental Development Councils. The Councils were established through the peace accords as a means of increasing participatory democracy in Guatemala. However the agreement does not delimit their duties and authority. The Law on Development Councils has been legally challenged as unconstitutional for its encroachment on federal authority. For a discussion of the Departmental Development Councils, see Gary Bland, Decentralization in Guatemala: The Search for Participatory Democracy, Woodrow Wilson Center Update on the Americas No. 3 (Mar. 2002), available at http:/www.wilsoncenter.org/topics/ pubs/DecentGuatemala.pdf. In 2005, the government granted a television license to the Academy of Mayan Language, enabling mass media programming in local languages of the indigenous population, and the following year the government created an AntiRacism Commission to support indigenous rights. See United Nations General Assembly, Durban Review Conference, ACONF.211/PC/RPM/1/2, 11 June 2008, at 7. 
Although former rebels now participate in the political process, stand for election, and hold office, successive democratically-elected governments in Guatemala have not achieved meaningful progress toward land reform. ${ }^{47}$ Nor has an expansion of opportunities for the country's indigenous population materialized..$^{48}$ In short, the root causes of the civil war largely remain unresolved.

\section{Northern Ireland}

The long running conflict in Northern Ireland was a product of religious conflict between Protestant and Catholic communities. British authorities partitioned Ireland in 1922, creating an independent Ireland. However, fear of Roman Catholics by Protestants living in the north led to Britain granting only limited autonomy to Northern Ireland. While Northern Ireland possessed much of the infrastructure of an advanced Western democracy, its citizens did not possess full governance rights. Thus, Northern Ireland in some ways exhibits a colonial legacy. While we recognize this to be a controversial statement, power has rested with the government of Westminster for most of its existence. Britain imposed direct rule on the territory in 1972, which ushered in the protracted period of political unrest known as "the Troubles." 49 Yet despite the often brutal violence committed by all parties during the conflict, legal institutions remained strong. For example, even the Irish Republican Army (IRA) sought redress in the courts for state restrictions on the rights of its supporters to engage in political protests, obtain recognition of jailed members as political prisoners, and restrain police abuses in Catholic communities. ${ }^{50}$

In December 1993, the parties issued a declaration termed "A New Framework for Agreement" that five years later led to the adoption, by popular referendum, of the Belfast Agreement. On its face, the Agreement addressed religious-based discrimination and the lack of popular rule in Northern Ireland that were at the root of the conflict. The Agreement also established a process to result in self-rule in Northern Ireland and legal

47. See Lisa Viscidi, La Platforma Agraria: Land Reform and Conflict in Guatemala, Counterpunch, 8 Sept. 2004, available at http://www.counterpunch.org/viscidi09082004.html.

48. Economic growth in the post-transition period is unimpressive; in 2007 almost half of the urban population (48 percent) lived in poverty and the GNI per capita was $\$ 2,440$. World Bank, Guatemala, Data and Statistics, Guatemala at a Glance (24 Sept. 2008), available at http://devdata.worldbank.org/AAG/gtm_aag.pdf.

49. See Christine Bell, Dealing with the Past in Northern Ireland, 26 Fordmam INT'L. L. J. 1095 (2003).

50. Though the Irish Republican Army may have pursued these avenues strategically, their efforts reveal that the courts had some legitimacy among disenfranchised groups. Stephen J. Brams \& Jeffrey M. Togan, Cooperation through Threats: The Northern Ireland Case, 31 J. Pol. Sa. 32 (1998). 
guarantees of human rights. ${ }^{51}$ The popular referendum endorsing the Belfast Agreement indicated that residents in Northern Ireland supported a political agreement that initially emphasized future political autonomy over retributive measures for past crimes. ${ }^{52}$

Since the Belfast Agreement ended the conflict in Northern Ireland, the parties have implemented some legal reforms ${ }^{53}$ although progress toward political autonomy has been frustratingly slow. In 2001, six years after the signing of the accords, a coalition of community-based groups established a program, "Healing Through Remembering." ${ }^{44}$ This program emerged from a consultative process involving the Deputy Chair of the South African Truth and Reconciliation Commission, Dr. Alex Boraine; the purpose of the project is to recommend measures to address the social cleavages of the troubles. At the same time another community-initiated project, the "Legacy Project," began to document and assess the needs of victims and is now funded by the government. ${ }^{55}$ Although no official reparations program exists for Northern

51. The Agreement: Agreement Reached in the Multi-Party Negotiations, 10 April 1998, available at $h t t p: / / w w w . n i o . g o v . u k / a g r e e m e n t . p d f$. The instrument officially devolved power from Westminster to democratic institutions of Northern Ireland and led to democratic elections and power sharing by political parties. Id. Since the agreement, political parties have made significant progress to institute the called-for legal reforms aimed at safeguarding individual rights and thus secure a lasting peace; in 1999 the Northern Ireland Human Rights Commission was established as called for in the Belfast Agreement. Id. See also Northern Ireland Human Rights Commission, About Us, available at http://www.nihrc.org/index.php?option=com_content\&task=view\&id=7\&Itemid=12. In 2000, the United Kingdom adopted the European Convention on Human Rights which automatically applied to Northern Ireland. However, British authorities interrupted the formal transfer of power to the Northern Ireland assembly and executive in 2000 and 2002, the main obstacle was disputes about the pace and extent of decommissioning of the IRA. See The Assembly after Devolution, Brief Summary, Northern Ireland Assembly, available at http://www.niassembly.gov.uk/io/summary/new_summary.htm\#7. These setbacks could have been characterized as a failure to resolve the underlying causes of the violence, but are distinct from political support to address the political crimes of the past.

52. The agreement did not provide for (or prohibit) prosecutions of crimes by the state or non-state actors. Northern Ireland Office, Media Center, Review of the Belfast (Good Friday) Agreement, available at http://www.nio.gov.uk/press/1998/jun/980601sos-nio. htm.

53. British and Irish Governments, Achievements in Implementation of the Good Friday Agreement, 14 July 2001, available at http://www.nio.gov.uk/achievements_in_implementation_of_the_good_friday_agreement.pdf; see generally Christine Bell, Dealing with the Past in Northern Ireland, 26 Fordham INT'L L.J. 1095 (2002).

54. See Healing Through Remembering site, available at http://www.healingthroughremembering.org/. For the history and development of the project, see "History," available at http://www.healingthroughremembering.org/c_htrinfo/history.asp.

55. See The Tim Parry and Jonathan Ball Foundation: The Legacy Project, available at http:// www.foundation4peace.org/rp-legacy-needs-analysis.htm. In 2006, the government in Northern Ireland began funding the Centre for Trauma and Transformation to address needs of all those affected by the Troubles. See Northern Ireland Centre for Trauma and Transformation, available at http://www.nictt.org. 
Ireland, the voices of survivors are influential in maintaining attention to addressing their distinct needs. ${ }^{56}$

On 8 May 2007, the two major rival political parties implemented a power-sharing government, a symbolic and tangible move to an integrated, autonomous Northern Ireland. ${ }^{57}$ However, despite the overall strong economic climate since the Belfast Agreement, ${ }^{58}$ the pace of reform raises questions regarding the ultimate ability of the parties to meet the political conditions at the heart of the Agreement.

\section{Sierra Leone}

The history of Sierra Leone's modern conflicts are rooted in its colonial past. The British established a protectorate over the territory in 1896. Post-colonial Sierra Leone was left with an imposed, dual system of justice; ${ }^{59}$ the English language, some English traditions, and inequality throughout the country resulted in a society that was fractured economically and politically. ${ }^{60}$ Staterun municipal courts are out of reach for most-physically remote from the villages and culturally "foreign." ${ }^{61}$ Western legal traditions have not become the dominant forum in which most citizens, and particularly those in rural areas, seek redress. This unstable situation has bedeviled the country since independence leading to coups, weak rule of law, a poor economy, and a one-party state. This legacy has made Sierra Leone vulnerable to manipulation by external forces.

56. In October 2005 British authorities established a Victims Commission to address the needs of victims of "the Troubles." In January 2008 the Northern Ireland Executive appointed four victim's commissioners to replace the interim commissioner. Row Brewing Over NI Victims' Bill, BBC News, 8 Apr. 2008, available at http://news.bbc.co.uk/2/hi/ uk_news/northern_ireland/7336615.stm.

57. Northern Ireland (St Andrews Agreement) Act 2007, 2007 Ch. 4, 27 Mar. 2007, available at http://www.opsi.gov.uk/ACTS/acts2007/ukpga_20070004_en_1; see also Northern Ireland (St. Andrews Agreement) Act, Explanatory Notes, available at hitp://www.opsi. gov.uk/ACTS/acts2007/en/ukpgaen_20070004_en.pdf; Paul Hoskins, N. Ireland's Parties Seal Power Sharing Deal, ReuTERs, 26 Mar. 2007, available at http://www.reuters.com/ article/worldNews/idUSL2658580520070326?feedType=RSS.

58. The Republic enjoyed the lowest rate of unemployment in the European Union from 2000 to 2005. European Commission, Living Conditions in Europe-Data 2002-2005, Eurostat Product Code KS-76-06-390 (2007), available at http://epp.eurostat.ec.europa. eu/cache/ITY_OFFPUB/KS-76-06-390/EN/KS-76-06-390-EN.PDF.

59. A.B. Cotay, Sierra Leone in the Post War World, 58 J. Afr. Aff. 210, 232 (1958); Timothr Kelsall, Law and Legal Institutions in an Upcountry Sierra Leonean Town (2006). The power exercised by Chiefs to adjudicate disputes frequently exceeded their constitutional mandate, leading to allegations of abuse, and corruption. Shaw, supra note 3, at 1, 11 .

60. There are thirteen ethnic groups in Sierra Leone and the colonists developed a system that placed power in the hands of the landowners-there was little opportunity for others to access resources. See E. Conteh Morgan, Mac Dixon-Fye, \& Peter Lang, Sierra Leone at the End of the Twentieth Century (1999).

61. Shaw, supra note 3 , at 1,11 . 
In 1991, a rural rebel movement formed, which soon allied itself to the neighboring Liberian regime of Charles Taylor. ${ }^{62} \mathrm{~A}$ bloody eleven year civil war soon followed (1991-2002). While it is difficult to attribute the civil war in Sierra Leone to a single or easily described set of tensions, socioeconomic conflict may be considered to have been a significant contributor. ${ }^{63}$ Tribal hierarchy and customs had established rigid controls over social and economic opportunity, particularly in rural areas. ${ }^{64}$ Popular dissatisfaction with tribal hierarchy, corruption, and repression enabled opposition groups to recruit members for armed resistance to the status quo.

The conflict saw the formation and dissolution of numerous rebel groups, governments, and the intervention of paid mercenaries. At the height of the conflict, nearly half of the population of 4.5 million was thought to be displaced internally or across the border, up to 50,000 people may have died, and a further 100,000 may have been mutilated. ${ }^{65}$

Peace finally came to Sierra Leone in 2002, as a result of disarmament facilitated by UN forces. Beginning in 1995, the international community became increasingly involved in attempts to end the horrors of the violence ${ }^{66}$ The near destruction of Freetown in 1999 led to the Lomé Accords in 1999. The agreement was supposed to end the violence by offering amnesties to the leaders of the Revolutionary United Front (RUF) ${ }^{67}$ At the same time, the

62. Q\&A: Sierra Leone's hostages, BBC News Special Report, 10 Aug. 1999.

63. Tim Kelsall, supra note 3.

64. Prior to the war, most of the population lived in the countryside dispersed in small settlements. Poor families depended on tribal leaders for assistance in times of shortages. A corollary to dependency was vulnerability to abuse by tribal leaders. Paul Richards, To Fight or to Farm? Agrarian Dimensions of the Mano River Conflict LLiberia and Sierra Leonel, 104 Afr. Aff. 571 (2005). Individuals could seek assistance from tribal leaders when crops failed or they otherwise found themselves unable to provide for their families. In return, family members pledged to work off the debt by tending the lands of the tribal leader. Such arrangements often result in exploitation and extended periods of bonded labor. Richard Fanthrope, Neither Citizen nor Subject: Lumpen Agency and the Legacy of Native Administration in Sierra Leone, 100 Afr. Aff. 363 (2001). Another factor that limited opportunities for younger members of the community is the practice by tribal chiefs of polygamy. A chief may have scores of wives, thereby limiting the possibilities for young men to establish families. Males who are found to have sexual relations with a wife of the tribal chief are sanctioned and may be forced to leave the community. Interview with Tim Kelsall, Senior Lecturer, Newcastle University, Berkeley, CA, (15 Nov. 2006).

65. Id

66. In 1995, the United Nations sent an envoy to work with the Organization of African Unity (OAU) and the Economic Community of West African States Monitoring Group (ECOMOG), a West African multilateral armed force, to restore civilian control. The Abidjan Accord of 1996 was derailed by yet another coup in 1997. The UN Security Council imposed an oil and arms embargo in 1997-98 and sent an observer mission (UNOMSIL) to monitor security as well as a disarmament program. It was succeeded by a larger force (UNAMSIL) in 1999. ECOMOG forcefully took over the capital in 1998, dislodging the Armed Forces Revolutionary Council-Revolutionary United Front junta, permitting the reinstallation of the official government.

67. Peace Agreement Between the Government of Sierra Leone and the Revolutionary United Front of Sierra Leone, Article IX: Pardon and Amnesty, Lomé: Togo, 7 July 1999, available at http://www.usip.org/library/pa/sl/sierra_leone_07071999.html $\$ 9$. 
Lomé Accords stipulated the creation of a Truth and Reconciliation Commission (SLTRC), which began operations two years later. ${ }^{68}$

In 2000, notwithstanding the Lomé Agreement, Sierra Leone's president, Ahmad Tejan Kabbah, requested the assistance of the United Nations in establishing a system to try those responsible for crimes committed during the violence. In January 2002, the United Nations and government of Sierra Leone signed an agreement establishing the Court-a hybrid operation with judges both from Sierra Leone and the international community. Its prosecutor was David Crane, a US citizen. As Kelsall has reported, the prosecutor approached the task with nearly religious fervor as the representative of Western law and beliefs. ${ }^{69}$

The United Nations initiated and facilitated the SLTRC in concert with civil society organizations. Two years after the 2004 final report, the Sierra Leone Working Group on Truth and Reconciliation released its preliminary study of the accomplishments of the TRC. The report described the process as "deeply flawed," externally imposed to some degree, and in conflict with the work of the Special Court. ${ }^{70}$ While not a universal set of opinions, others have questioned the TRC's relevance to the people of Sierra Leone. ${ }^{71}$

Only a brief post-conflict record exists (since 2002) to evaluate the efforts of the state to address economic and social structural inequities. In 2005, the country posted an unemployment rate of 70 percent and 50 percent of

68. The UN Office of the High Commissioner for Human Rights and the International Center for Transitional Justice, assisted in the implementation of Truth Commission.

The TRC Act of 2000 under Part 3 describes its goals:

The object for which the Commission is established is to create an impartial historical record of violations and abuses of human rights and international humanitarian law related to the armed conflict in Sierra Leone, from the beginning of the Conflict in 1991 to the signing of the Lomé Peace Agreement; to address impunity, to respond to the needs of the victims, to promote healing and reconciliation and to prevent a repetition of the violations and abuses suffered.

Sierra Leone's Truth and Reconciliation Commission Act 2000 (Feb. 2000), available at http://www.usip.org/library/tc/doc/charters/tc_sierra_leone_02102000.html

69. Tim Kelsall, Politics, Anti-Politics, International Justice: Language and Power in the Special Court for Sierra Leone, 32 Rev. INT'L Stud. 587 (2006). Crane's zeal is apparent in his opening statement:

On this solemn occasion mankind is once again assembled before an international tribunal to begin the sober and steady climb upwards towards the towering summit of justice. The path will be strewn with the bones of the dead, the moans of the mutilated, the cries of agony of the tortured echoing down into the valley of death below. Horrors beyond the imagination will slide into this hallowed hall as this trek upward comes to a most certain and just conclusion. The long dark shadows of war are retreated. Pain, agony, the destruction and the uncertainty are fading; the light of truth, the fresh breeze of justice moves freely about this broken and beaten land. The rule of law marches out of the camps of the downtrodden onward under the banners of never again and no more.

David M. Crane, The Prosecutor, Special Court for Sierra Leone, Opening Statement, 3 June 2004, available at http://www.sc-sl.org/Press/prosecutor-openingstatement060304. pdf.

70. Pambazuka News, Sierra Leone: Searching for Truth and Reconciliation, 3 Feb. 2006, available at http://www.pambazuka.org/en/category/rights/32427.

71. Shaw, supra note 3 , at 130. 
the government budget came from international donations. ${ }^{72}$ Recently, the government passed new laws to attract investment, reduce corporate taxes, and tackle land reform. As a result, the economic outlook is promising. ${ }^{73}$ However, fundamental questions regarding tribal rule-how control over resources and wealth will be allocated-remain unanswered and will undoubtedly impact political stability in the long term.

\section{South Africa}

Apartheid-systematic state-sponsored racial discrimination-defined the underlying conflict in South Africa. The system was deeply rooted in the colonial model of governance, ${ }^{74}$ which enhanced the drama of its sudden collapse. The country's transition to a one-person-one-vote democracy transferred power literally overnight to the Black African majority, in the form of the African National Congress (ANC) party. This transition was made possible by leaders who believed in democracy and unity. ${ }^{75}$

Subsequent progress to rectify race-based inequalities has been steady but incremental. ${ }^{76}$ There is still a great unmet need, and a concomitant displeasure, with massive unemployment, societal unrest, and significant crime rates. ${ }^{77}$ To date, these persistent disparities do not appear to pose an immediate threat to the new constitutional order. ${ }^{78}$

The freely elected, ANC-dominated government in South Africa addressed the past through the National Reconciliation Act in $1995 .{ }^{79}$ The Act

72. Id.

73. Legalization of the diamond trade has contributed to economic growth-official exports of the gem for the first 6 months of 2005 were $\$ 54$ million, compared to $\$ 9$ million in 1990. The International Monetary Fund predicted in 2006 that the Sierra Leonean economy would continue to grow at 7 percent. International Monetary Fund, Public Information Notice (PIN) No. 5/05, 19 Jan. 2005, available at http://www.imf.org/external/ np/sec/pn/2005/pn0505.htm.

74. See Alan Drury, "A Very Strance Society": A Journey to the Heart of South Africa (1967).

75. Martha Minow, Between Vengeance and Forgiveness: Facing History After Genocide and Mass VIOLENCE (1998).

76. In 1994, the first year of free elections, the new government passed limited land reform to resolve through mediation the land claims of Black Africans forcibly removed in 1913 as part of the state's land use policy. The 1996 Constitution enshrined economic rights for all citizens including the rights to housing, education, and health care. The following year, the government enacted a series of laws to implement these rights. Social service spending increased beginning in 2001, with increased expansion of child services and increases to subsidies for the elderly and children.

77. The Presidency of the Republic of South Africa, Development Indicators 2008, Safety and Security, 60, available at http://www.info.gov.za/view/DownloadFileAction?id=85218.

78. The recent wave of xenophobia, rioting and killings of foreign nationals in the country may have its roots in the lack of employment opportunity and economic disparity that persists. See Romi Fuller \& Nahla Valji, South Africa: Scarcity Sets Fire to Country's Xenophobic Tinderbox, Bus. DAY (Johannesburg), 22 May 2008, available at http://allafrica. com=/stories $/ 200805220118 . \mathrm{html}$.

79. Office of the President, No. 34 of 1995, Promotion of National Unity and Reconciliation Act No. 1111 (26 July 1995). 
established a legal framework for accountability and allowed perpetrators of political violence committed during apartheid to receive amnesty if they made a full disclosure of their crimes ${ }^{80}$ The vast majority of individuals who applied for amnesty under the Act were black South Africans; the Afrikaner political leadership rejected the Commission, and few white members of the apartheid regime stepped forward. ${ }^{81}$ The TRC, supported by the ANC, became the symbolic cornerstone for the transition of the state to a full democracy. In 2000, six years after the country's first free elections, the TRC concluded its work. Publication of the commission's final report occurred in March $2003 .{ }^{82}$ Under the terms of the Act, the TRC made recommendations to the President regarding the shape and scope of reparations to victims. President Thabo Mbeki announced in June 2003 that the government would compensate victims at one quarter of the amount recommended by the TRC. ${ }^{83}$

While victims' groups have criticized the government's reparations program as paltry, the government has continued to make modest progress towards introducing legal and social reforms to address the deep and persistent economic and social inequities that continue to divide South Africans. ${ }^{84}$ The government's political commitment to democracy and human rights is critical. It contributes to the maintenance of political stability even while persistent black-on-black violence points to the significant social unrest. ${ }^{85}$

Despite a strong court system that anti-apartheid groups used, even at the height of apartheid, to undermine aspects of state power by challenging legislation, exposing state-sanctioned violence, and enforcing legal protections of the rights of non-white residents, ${ }^{86}$ there have been few trials of state

80. Id. ch. 5 .

81. Timothy Sizwe Phakathi \& Hugo van der Merwe, The Impact of the TRC's Amnesty Process on Survivors of Human Rights Violations, in Truth AND ReCONCLIATION IN SOUTH Africa: Did the TRC Deliver? 119 (Audrey R. Chapman \& Hugo van der Merwe eds., 2008). Black applicants comprised 58 percent of the total amnesty applications and whites 39 percent. Id. at 119, n.8. See also Therese Abrahamsen \& Hugo van der Merwe, Reconciliation through Amnesty?: Amnesty Applicants' Views of the South African Truth and Reconciliation Commission, Centre for the Study of Violence and Reconciliation 4 (2005), available at http://www.csvr.org.za/docs/trc/reconciliationthroughamnesty.pdf; Alex Boraine, A Country Unmasked (2000).

82. South African Government Information, Truth and Reconciliation Commission of South Africa Report (21 Mar. 2003) available at http://www.info.gov.za/otherdocs/2003/trc/.

83. Victims' groups and NGOs criticized the government scheme as insufficient. Legally foreclosed from pursing criminal or civil suits against perpetrators who participated in the TRC process, victims groups believed that justice for victims had been sacrificed for political and monetary expediency. Warren Buford \& Hugo Van der Merwe, Reparation in Southern Africa, 44 Cahiers d'Etudes Africaines 1, 1, 2 (2002).

84. Christopher J. Colvin, "We Are Still Struggling": Storytelling, Reparations and Reconcilation AFTER THE TRC (2000), available at http://www.csvr.org.za/docs/trc/wearestillstruggling. pdf.

85. James Gibson \& Amanda Gouws, Overcoming Intolerance in South Africa: Experiments in demoCRATIC PERSUASION (2003).

86. The autobiography of Nelson Mandela, a South African trained lawyer, reveals how early activists tried to use the legal system to counter apartheid laws. Nelson MandeiA, LONG WAIK to Freedom (1994). 
authorities or ANC members for political crimes committed during apartheid. ${ }^{87}$ Trials, at this point, appear to be relegated to a secondary position.

There seems to be a fragile societal consensus regarding the government's commitment to progressive, incremental redress of structural inequalities. However, the failure of the government to provide sufficient material improvements to its poor population may, over time, cause this compact to be renegotiated.

\section{Timor-Leste}

A long-time colony of Portugal, Timor-Leste was annexed by Indonesia in 1976. During the twenty-four-year occupation by Indonesia, a quarter of the island's population is thought to have died ${ }^{88}$ Following President Suharto's resignation, his successor, President Habibie, offered limited autonomy to the territory and agreed to allow a referendum on full autonomy. Increasing violence ensued, much of it instigated by militias armed and organized by Indonesia. As has been well-documented, the referendum led to mass violence and killings, and in September 1999, the United Nations sent in a multinational force, the International Force for East Timor (INTERFET) to secure the region. The troops remained in place until February 2000, when they turned over responsibility to the UN Transitional Administration in East Timor (UNTAET). UNTAET essentially operated as the government of the territory until May 2002, when its military functions were transferred to the UN Mission of Support to East Timor. ${ }^{89}$ James Traub wrote that UNTAET's

87. Eugene De Kock, a colonel who commanded the Vlakplaas counterinsurgency group, the highest ranking official to be convicted for his involvement in apartheid-era atrocities, was found guilty of eighty-nine crimes including six murders. Suzanne Daley, South African Police Colonel Jailed for Life in Apartheid Killings, N.Y. TImes, 31 Oct. 1996, at All. De Kock applied for and was granted amnesty from the Truth and Reconciliation Commission. See Press Release, Truth and Reconciliation Comm'n, De Kock Granted Amnesty (2 June 2000), available at http://www.csvr.org.za/wits/papers/papr2r1.htm. Minister of Defense Magnus Malan was also tried and acquitted of murder. See John Dugard, Reconciliation and Justice: The South African Experience, 8 TranSNAT'L L. \& Contemp. Probs. 277, 299-300 (1998). Martin Meredith, Cominc to Terms: South Africa's SEARCH FOR TRUTH 46-54, 355 (1999). Such experiences disillusioned many victims who still feel that they have not received justice from either the TRC or the criminal justice system. See From Rhetoric to Responsibility: Making reparations to the surviviors of past poltiCAL VIOLENCE IN SOUTH Africa (Brandon Hamber \& Tlhoki Mofokeng eds., 2000), available at http://www.reconciliation.org.za/trc/rhet.htm.

88. The story of international intervention in Timor-Leste is complicated by the sacrifice of its people to international interests during the Cold War. Joseph Nevins, (Mis)representing East Timor's Past: Structural-Symbolic Violence, International Law, and the Institutionalization of Justice, 1 J. Hum. Ris. 523 (2002); Simon Philpott, East Timor's Double Life: Smells like Westphalian Spirit, 27 THIRD WORLD Q. 135 (2006).

89. See U.S. Dep't of Siate, 2002 Country Reports on Human Rights Practices: East Timor (2002). 
mission was "an exercise in benevolent colonialism." ${ }^{90}$ In fact, there were serious complaints of exclusion of the East Timorese people from the process establishing a government and its infrastructure. ${ }^{91}$

In 2000, UNTAET established the Serious Crime Unit (SCU) and the Special Panels in Timor-Leste to adjudicate serious crimes committed prior to 25 October 1999. David Cohen's 2005 report details the serious deficiencies and United Nations bumbling that plagued the operation of that court. ${ }^{92}$ In April 2001, the Timor-Leste National Council approved the formation of the Commission for Reception, Truth and Reconciliation-a truth commission with power to allow perpetrators of less serious crimes to admit culpability and receive punishment of community service, a program that incorporated elements of Timor-Leste culture. ${ }^{93}$

Timor-Leste's independence from Indonesia addressed the initial cause of the violence: repressive Indonesian rule. However, the legacy of the twenty-four year occupation requires building human as well as physical infrastructure in order to maintain democracy. The nascent development of the state leaves little record to evaluate its progress toward meeting the basic needs of its new citizens. The country lacks a developed civil service system, judicial institutions, a sustainable economy, and a profound mistrust of state authorities persists..$^{94}$ The 2006 rioting in Dili and the recent assassination attempt on its President further indicate the relative inability of the state to provide security.

90. Jose Manuel Puerza, Who Saved East Timor? New References for International Solidarity, 9 S. Eur. Soc'Y \& Pol, 191 (2004).

91. The irony is that the international community acquiesced in the annexation, failed to respond to the years of oppression, and when it finally became engaged in assisting the Timorese, the intervention continued the disenfranchisement of Timor-Leste's people. The ambivalent support offered to the Special Panels in resources and efficient operation undermined the efficacy of judicial intervention.

92. David Cohen, Justice on the Cheap Revisited: The Failure of Serious Crimes Trials in Timor Leste (2005).

93. The holding back of the truth commission report (likely in response to the importance of Timor-Leste's relationship with Indonesia) further suggests that timing and sequence were critical factors in this country as well. In December 2004, a Commission of Truth and Friendship (CTF) Indonesia and Timor-Leste was formed by the governments of the respective states to examine the "truth" of what had transpired before, during, and after the 1999 violence in Timor-Leste. In July 2008, the Commission submitted its report and acknowledged that the Indonesian government held responsibility for the massive human rights violations that had taken place in Timor-Leste. The report focused on the events of 1999 and chose to ignore the antecedents to the conflict suggesting that the Commission's work was basically a compromise sanctioned by the two governments. While the government of Indonesia accepted the report, the government also decided not to pursue any legal accountability. See available at http://www.ctf-ri-tl.org/ctf1/index. php?option=com_content\&task=view\&id=87\&Itemid=71 T; http://www indonesia-ottawa . org/information/details.php?type=news_copy\&id=5339; http:// www.thejakartapost.com/ news/2008/07/22/ctf-report-burying-some-inconvenient-truth.html.

94. The perceived betrayal of the international community at the time of annexation and the failure of the Timor-Leste court reinforce the sense of powerlessness and lack of trust that threaten stability in the country. See Caitlin Reiger, Hybrid Attemps at Accountability for Serious Crimes in Timor Leste, in Transitional Justice in the 21" Century: Beyond Truth veRSUS JUSTICE 143 (Naomi Roht-Arriaza \& Jose Mariezcurrena eds., 2007). 


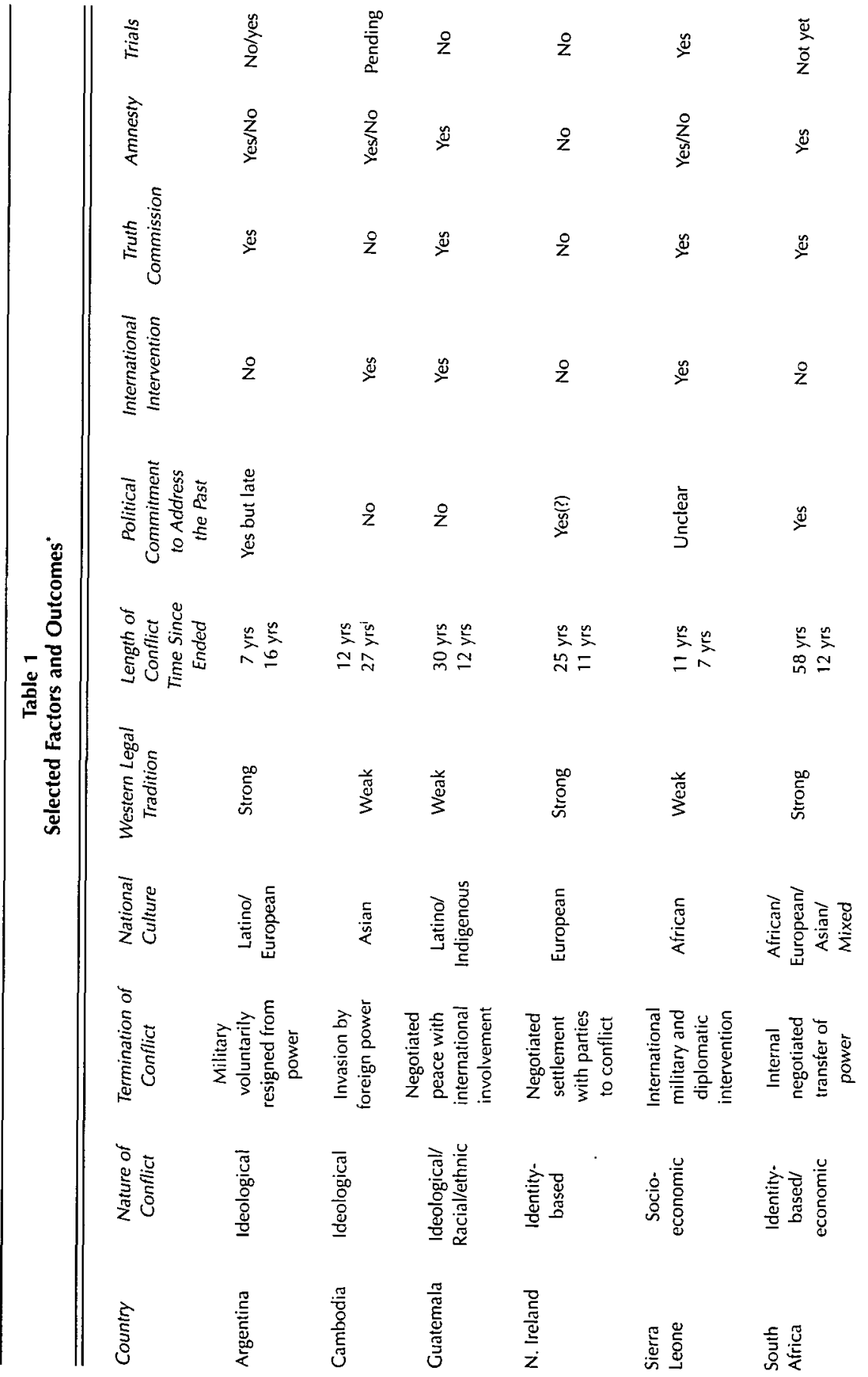




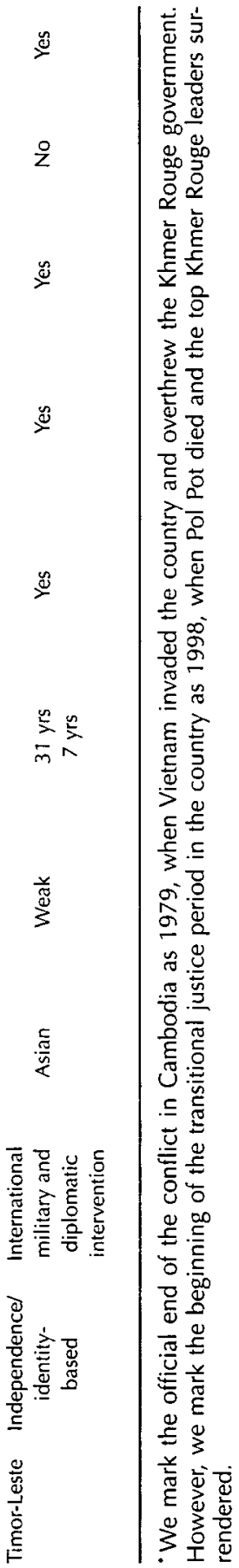




\section{FINDINGS}

Based on the analysis of the case studies, eight factors emerged as significant influences on the manner in which countries responded to mass human rights violations committed by a prior regime and the impact of transitional justice mechanisms: (1) the strength and legitimacy of legal institutions, (2) the strength of democracy prior to the conflict, (3) the legacy of colonialism; (4) the character of the country as a failed or decimated state, (5) international intervention in the country, (6) the commitment of governing parties to confront the past, (7) interventions since the transition to democracy to address underlying structures and power inequities that contributed to the conflict, and (8) the time since the onset of the transition period and its relevance to addressing the articulated needs of survivors. Table One summarizes the relationship between the case study countries and the factors.

We will describe each factor, its relationship to the case studies, and its relevance to the country's choice of transitional justice interventions. The discussion section identifies the patterns that emerge among the factors. The patterns offer insights into the importance of conducting a comprehensive inventory of baseline institutional, cultural, political, and legal resources and incorporating these data into decisions by local, national, and international authorities in designing and implementing transitional justice initiatives.

\section{A. Strength and Legitimacy of Legal Institutions and Strength of Democracy}

The strength of the rule of law in a country prior to conflict, as well as the legitimacy and esteem given to legal institutions, emerged as salient features in the case studies. For purposes of this analysis, the rule of law encompasses the development of legal rules and institutions based on principles of Western liberal theory. Legal customs, practices, and institutions based on indigenous, non-Western, or otherwise alternative to state-sponsored legal institutions play an important role in many of the countries we studied, yet are not included in this analysis. Here we focus our attention on the status enjoyed by state-sponsored legal institutions..$^{95}$

The legitimacy of legal institutions within societies refers to public attitudes toward and confidence in state-sponsored legal institutions. ${ }^{96}$ Whether

95. Alternatives to official rule of law institutions may prove particularly important to transitional justice mechanisms yet are beyond the scope of this study. However, we consider the interplay of state-sanctioned and alternative legal practices in our discussion of the findings.

96. Public attitudes also may be influenced by the role of judges in a legal system, particularly in post-colonial countries. There may be differences between the perceived legitimacy 
societies implement purely domestic transitional justice programs or whether the United Nations establishes trials, truth commissions, or other interventions, these programs will confront general attitudes toward national law and legal institutions. Of the countries selected, most have weak legal institutions and low legitimacy. Cambodia, Guatemala, Sierra Leone, and Timor-Leste fall into this category. In contrast, Argentina, Northern Ireland, and South Africa possess legal systems in which the judiciary enjoys popular legitimacy, despite the political polarization that plagued each of these countries.

Countries with strong rule of law and independent judicial systems were not necessarily indicative of strong democracies. For purposes of the case analysis, democracies are measured by the extent to which a country is fully independent with universal franchise, possesses a constitutional government, and in which political conflict, however sharp, is managed nonviolently through an internal system of checks and balances. ${ }^{97}$

\section{Countries with weak rule of law, low public confidence in the judicial system, and weak democracies}

As indicated by our case studies, those countries with weak rule of lawCambodia, Guatemala, Sierra Leone, and Timor-Leste-suffered from a long history of low public confidence in public governance structures. Western legal traditions have not become the dominant forum in which most citizens, and particularly those in rural areas, seek redress.

in each of these countries, since the official end of conflict, the judicial system remains marred by poorly trained, corrupt, or indifferent judges and staff. Chronic lack of human and physical infrastructure contributes to the inability of these legal systems to administer justice. The lack of resources for judicial infrastructure-physical facilities, adequate record-keeping procedures, and sufficient court personnel to manage the docket-also compromises the capacity of legal institutions. Corruption, police misconduct, and poor prison conditions attest to weak state structures to administer laws fairly. ${ }^{98}$ Persistent political violence as well as opportunistic or street level

of common law judges-who are independent decision makers "finding" the law-and civil law judges-state civil servants who apply the legal code to the particular case. However, this is a variable we do not explore in this article. See Martin Shapiro, Courts: A Comparative and Political Analysis (1986).

97. For further analysis of democratic theory, see Guillermo O'Donnell. et al., The Quality of Democracr: Theory and Applications (2004).

98. Transparency Int'L, Corruption Perception Index (2007), available at http://www.transparency. org/content/download/34227/533558.

The 2007 Corruption Perceptions Index looks at perceptions of public sector corruption in 180 countries and territories . . . and is a composite index that draws on 14 expert opinion surveys. It scores countries on a scale from zero to ten, with zero indicating high levels of perceived corruption and ten indicating low levels of perceived corruption. ... A strong correlation between corruption and poverty continues to be evident. Forty percent of those scoring below three, indicating that corruption is perceived as rampant, are classified by the World Bank as low income countries. 
crime also point to the failure of these post-transition states to provide for the basic security needs of their populations. And of course, low economic growth in all of these countries deprives the state of finances needed to invest in rule of law measures. ${ }^{99}$ Finally, the lack of democracy in these countries prior to the conflict also contributes to weak institutional infrastructure needed to establish stable societies after the fighting is over. ${ }^{100}$

\section{Countries with strong rule of law, high public confidence in the judicial system, and stronger democracies}

In contrast to the countries with weak legal traditions, Argentina, Northern Ireland, and South Africa all boast well-developed legal institutions and a tradition and culture of generally resorting to courts to enforce rights. In each country, prior to and even to some extent during the conflicts, courts in these countries possessed a cultural legitimacy and enjoyed, within limits, a reputation for independence and impartiality. ${ }^{101}$ In each country, the courts

Each of the countries in our study characterized as weak have rule of law scores below 3 in the Transparency International Index: Cambodia 2.0; Guatemala 2.8; Sierra Leone 2.1; and Timor-Leste 2.6. Low scores in the index "indicate that public institutions are heavily compromised." Id., available at http://www.transparency.org/news_room/latest_news/press_releases/2007/2007_09_26_cpi_2007_en.

99. The United Nations Development Programme 2007-2008 annual human development index $(\mathrm{HDl})$ "provides a composite measure of three dimensions of human development: living a long and healthy life (measured by life expectancy), being educated (measured by adult literacy and enrolment at the primary, secondary and tertiary level) and having a decent standard of living (measured by purchasing power parity, PPP, income)." In the most recent $\mathrm{HDI}$, Cambodia ranked $131^{\text {st }}$ of 177 countries rated, UNDP Country Report Fact Sheets-Cambodia, available at http://hdrstats.undp.org/countries/country_fact_sheets/cty_fs_KHM.html; Guatemala ranked $118^{\text {th }}$, UNDP Country Report Fact Sheets_Guatemala, available at http://hdrstats.undp.org/countries/country_fact_sheets/ cty_fs_GTM.html; Sierra Leone ranked last, $177^{\text {th }}$, UNDP Country Report Fact SheetsSierra Leonoe, available at http://hdrstats.undp.org/countries/country_fact_sheets/ cty_fs_SLE.html; Timor-Leste ranked $150^{\text {th }}$, UNDP Country Report Fact Sheets-Timor-Leste,

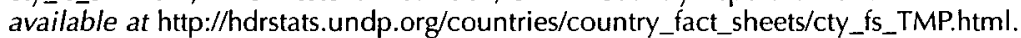

100. In Cambodia and Timor-Leste, there was no pre-conflict experience of national selfgovernance upon which the citizens might draw; they were starting from scratch. In Guatemala, the civil war expressed the inability of the democratic process to contain and resolve the underlying struggle for control of the country's resources between the minority Ladino and the majority indigenous population. Sierra Leone gained independence in 1961, but political instability plagued the fledging democracy, leading in 1978, to a constitutionally-created one-party state. Violent overthrow of the state became the focus of the Revolutionary United Front (RUF) which produced the bloody conflict. Thus, for most of the post-colonial period, the country has been a one-party state with little opportunity to develop democratic institutions directly accountable to citizens.

101. See alan Drury, a Very Strange Society: A Journer to the Heart of South Africa (1967); Graciela R. Montaldo \& Gabriela Nouzelles, The Argentina Reader: History, Culture, Poltics (2002); Bell, supra note 49, at 1095, 1128; Kieran McEvoy, Human Rights, Humanitarian Interventions and Paramilitary Activities in Northern Ireland, in EQUALTY, AND DemoCratic Renewal in Northern Ireland 215 (Colin J. Harvey ed., 2001). We are aware that under the apartheid regime in South Africa, the courts were complicit in upholding the 
served as a legitimate site of struggle prior to and during the conflict for the protection of opposition groups and their supporters; although in each instance dissident groups also resorted to violence to pursue their political agendas.

Yet the countries in our study with strong rule of law and independent judicial systems were not necessarily full democracies. Argentina, ${ }^{102}$ Northern Ireland, ${ }^{103}$ and South Africa ${ }^{104}$ suffered from significant democracy deficits, yet maintained court systems as pillars (even if illusory) of the rule of law. Against this backdrop, the ability of political opponents to resort to the courts speaks to the legitimacy of judicial institutions, even if the use of judicial mechanisms by opponents of the respective governments was strategic.

laws promulgated by the Nationalist Parliament. According to the report of the TRC, establishment bodies argued that "the doctrine of parliamentary sovereignty under the Westminster system required of lawyers (and especially judges) to respect, and indeed defer to, the will of the majority in Parliament, thus denying the courts the opportunity to fashion statute law to achieve a degree of justice in the face of legislated injustice." TRC FINAL REPORT: VOL. 4, at 95-96 (1998), available at hitp://www.doj.gov.za/trc/report/ finalreport/TRC\%20VOLUME\%204.pdf. This argument was rejected by the TRC. DAVID Dyzenhaus, Judging the Judges, Judging Ourselves: Truth, Reconciliation and the Apartheid Legal ORDER (1998), notes in his book, the foundation of legal order is a functioning democracy which was not a fact of life for the majority of South Africans.

However, during the apartheid era, the structures of the judiciary, the training of lawyers, and adherence to legal principles suggests that a tradition of rule of law existed although this window dressing was subterfuge for a system that had lost the ability to provide a check on state abuses. As with other professional groups in the country, e.g., physicians, lawyers were well trained although the profession itself did little to challenge the principles that governed the state. The minority of lawyers who challenged the apartheid regime and represented those engaged in the struggle suggests that this tradition, while warped, was an important value. Further, the development of the new constitution and the establishment of the Constitutional Court indicate that across the racial divide there was respect for the idea of a strong legal system.

102. Political instability and military coups mark Argentina's political landscape beginning in the 1930s. The 1976 coup was not an aberration but rather a continuation of military involvement in political life of the country.

103. British authorities partitioned Ireland in 1922, creating an independent Ireland. However, fear of Roman Catholics by Protestants living in the north led to Britain granting only limited autonomy to Northern Ireland. Thus, while Northern Ireland possessed much of the infrastructure of an advanced Western democracy, its citizens did not possess full governance rights. Britain imposed direct rule on the territory in 1972, which ushered in the protracted period of political unrest known as "the Troubles." See Bell, supra note 49 , at 1095.

104. The Afrikaner-dominated apartheid government deprived black South Africans of the legal franchise. Following the March 1960, Sharpeville Massacre during which the South African police opened fire on a group of Blacks protesting apartheid laws, killing sixtynine and injuring 180, the government imposed a state of emergency and outlawed the dominant Black political parties, the African National Conference, and the Pan African Congress. David Dyzenhaus, Judging the Judges, Judging Ourselves: Truth, Reconciliation and the Apartheid Legal Order 7 (1998). However, these political institutions continued to operate illegally and served a critical institutional role in the transition to democracy. 


\section{B. Rule of Law and Democracy and Transitional Justice Mechanisms}

The strength of the court systems and their use by political opposition prior to and during the periods of repression in the strong rule of law countries we studied-Argentina, Northern Ireland, and South Africa-did not lead to criminal prosecutions in the immediate post-transition period.

Of the states with weak legal institutions and weak democracies (or occupied territories)-Cambodia, Guatemala, Sierra Leone, and TimorLeste-all but Cambodia established truth commissions to generate an authoritative public record of the past atrocities. Sierra Leone and Timor-Leste have cooperated with UN efforts to establish hybrid criminal tribunals to prosecute those responsible for war crimes. After the surrender of the Khmer Rouge, Cambodia never erected a legal barrier to prosecutions and even asked for trials. ${ }^{105}$ However, it has been slow to initiate prosecutions and has done so under considerable pressure from the United Nations (which has insisted on international involvement in war crimes trials to ensure their legitimacy). ${ }^{106}$

We also found that the impact of truth commissions was diminished in countries with weak legal traditions. Those countries did not build on truth commission reports to initiate structural change. The lack of response to report recommendations suggests these commissions largely served a symbolic function.

Our findings suggest that countries utilize truth commissions to ease democratic transitions, regardless of the strength of their legal systems. However, these governments appear more interested in the symbolic value of truth commissions to review the past, rather than as a blueprint for structural or programmatic change. Yet, as demonstrated by Argentina, Northern

105. In the aftermath of the withdrawal of Vietnamese forces, in 1994, the Cambodian government offered amnesty to Khmer Rouge foot soldiers who surrendered. Loi Relative à la Mise Hors-la-Loi de la Clique du Kampuchea Democratique (1994) (Cambodia), art. 1 (on file with authors). This program did not apply to the Khmer Rouge leadership. However, the law permitted the King to issue individual pardons and in 1996, King Sihanouk pardoned former Khmer Rouge Deputy Prime Minister, leng Sary. Royal Decree (Reach Kret) No. NS/RKT/0996/72, 14 Sept. 1996 (on file with authors). Following increasing domestic and international pressure, the United Nations adopted Resolution 1997/49 in April 1997, which requested the Secretary General through his Special Representative, to examine any request for assistance in responding to past serious violations of Cambodian and international law. The Cambodian government followed with a letter dated 21 June 1997, signed by the then co-Prime Ministers, Prince Norodom Ranariddh and Hun Sen, requesting the assistance of the United Nations and the international community in "bringing to justice those persons responsible for the genocide and crimes against humanity during the rule of the Khmer Rouge from 1975 to 1979. Cook, supra note 31 , at $1,3,4$.

106. James Goldstone, Foreword: An Extraordinary Experiment in Transitional Justice, The Extraordinary Chambers, Open Society Justice Initiative 1 (2006), available at http:// www.justiceinitiative.org/publications/jinitiatives; Cook, supra note 31, at 1, 3, 4. 
Ireland, and South Africa, countries with strong legal systems are not equated with prosecutions. Only in countries with weak legal systems and intense UN involvement are criminal justice proceedings being instituted against a limited set of perpetrators.

\section{The Legacy of Colonialism}

The legacy of a colonial era is found primarily in three areas: first, the presence of in-groups with access to power and the exclusion of out-groups (a system that may be racially based). Second, hybrid judicial systems that attempt to combine Western judicial structures and law with rural, often tribal-based customary law. These hybrid systems may result in two forms of law where the urban areas use the Western standards and the rural areas seek justice in chief-run settings with no set standards, marked variation in punishments, gender bias, nepotism, and crony influence. ${ }^{107}$ Third, a distinct lack of trust that is frequently found in Western or developed country interventions, leading to charges of imperialism. These components of the colonial legacy are found most clearly in Cambodia, Guatemala, Sierra Leone, and Timor-Leste. In Argentina, Northern Ireland, and South Africa, these effects are muted by the development of stronger governance structures. ${ }^{108}$

The colonial systems created a mixed legacy-many of the newlyindependent countries were left with the trappings of democracy but with little commitment to their functioning or the resources to maintain institutional capacity at pre-colonial levels. Governments tended to recapitulate the abuses of the colonial regime and corruption soared with a widening of the divisions between the haves and the have-nots. In virtually every country the elite seized on opportunities to enrich themselves from public coffers. The tendency of some colonial powers to single out a specific group for political favor and influence created divisions that paved the way for conflict

107. Among our case studies, the clearest examples of hybrid legal systems are Sierra Leone and Timor-Leste, In Sierra Leone, the British divided the country into chiefdoms, ruled by an independent chief appointed for life, with a judicial and security system outside the Western modeled system. Local councils appointed chiefs from among the recognized ruling families. Richard Fanthrope, Lumpen Agency and the Legacy of Native Administration in Sierra Leone, 100 Afr. AfF. 400 (2001). In Timor-Leste, there is a ritual and political authority among each community, the political authority viewed as dealing with the profane. The communities were arranged in kingdoms whereby the political leader, the king, was silently guided by the ritual leader. TANIA HOLE \& ROD NixON, RECONCILING Justice: Traditional Law and State Judiciary in East Timor (Jan. 2003), available at hittp://www. jsmp.minihub.org/Traditional\%20Justice/Reports/ReconcilingJusticeReport.doc.

108. In South Africa, notwithstanding the Bantustan system established under apartheid, white state courts, even though compromised, held legitimacy as a democratic structure that could be built on post-apartheid. This stands in contrast to Cambodia, Sierra Leone, and Timor-Leste. 
after the colonists' departure. Related to this, education systems created by colonizers frequently forced instruction in the language of the colonial power and disenfranchised the indigenous communities. By maintaining this system in the post-colonial era, these states concentrated power in the hands of a small and favored group. Such an educational system inevitably affects opportunities for political and economic power, especially among native peoples. Finally, the post-colonial states often replicated prior patterns of repression of dissident voices often using laws that were established by the colonial power but adapted to serve the purposes of the post-colonial, independent government.

If we examine the relationships of the colonial legacy to the choice of transitional justice interventions, we see some interesting associations. In Cambodia, Guatemala, Sierra Leone, and Timor-Leste, the colonial legacy contributed to the emergence of conflict. Once again, these countries have chosen truth commissions or trials with strong support or pressure from the international community, thus compromising state sovereignty for accountability. There appears to be a dynamic interaction between the relative strength of the state and the involvement of the international community as represented by the United Nations. It is possible that the ambivalence shown by Guatemala and Cambodia towards follow-through on these projects, and the mixed response to the Sierra Leone Truth Commission, reflects an ambivalence left over from the past, especially from those whose voices were ignored during the colonial period.

In South Africa, Northern Ireland, and Argentina, respect for national institutions has allowed the states to choose their own pathways. Northern Ireland and South Africa are noteworthy in this regard. In each, progress was constrained by identity politics left over from the colonial period but institutional respect and strength trumped or will trump the racial/religious differences. In fact, the attention paid to human rights concerns in Northern Ireland during the last eight years suggests that this higher order of respect for the rights of all is a positive legacy of the past. It has allowed Northern Ireland to dispense with the usual transitional justice mechanisms and enabled South Africa to develop its own response to the evils of apartheid. ${ }^{109}$

\section{Failed or Weak States}

For the purposes of this analysis, we will use the definitions of weak states that were put forward in the report of the 2004 Commission for Weak States and US National Security. ${ }^{110}$ The report suggests that an effective govern-

109. For further discussion, see Bell, supra note 49, at 1095.

110. Jeremy M. Weinstein, John Edward Porter \& Stuart Eizenstat, On the Brink, Weak States and US National Security (2004). 
ment sustains at least three functions: "ensuring basic security" (both from external enemies as well as internal insurgencies), "meeting the basic needs of its citizens" including health and education, and "maintaining legitimacy" (governmental structures are transparent, accessible, and accountable). A weak state often means that the human resources necessary for a functioning democracy have been substantially diminished through violence and repression. ${ }^{111}$ Obviously, this has consequences for re-establishing a functioning state as both the human and physical infrastructure has been destroyed.

In this article, we apply these definitions to describe states pre-conflict and during the post-conflict era.

Cambodia, Guatemala, Sierra Leone and Timor-Leste, are examples of weak states. In all the weak states, the legal system is one institution that is consistently compromised. Often beset by corruption, government interference, poorly trained judges, and lack of due process, these states often fail to operate under the rule of law.

Northern Ireland and South Africa have been strong states that, despite significant problems that are well-documented, have shown stable, consistent government (although Northern Ireland has for many years been under direct rule from Westminster) and South Africa has been a strong state capable of providing that which it chose to provide to those whom the apartheid state saw as legitimate citizens. ${ }^{112}$ And finally, as we have noted, despite its turbulent history, the government of Argentina has for the most part been accountable to its people.

\section{Strength of state and transitional justice mechanisms}

Three weak states have held truth commissions (Guatemala, Sierra Leone, and Timor-Leste). All of these have followed some level of intervention by the United Nations. These same countries have held trials, once again under the aegis of international agencies or largely compelled by decisions of international institutions (the Inter-American Court for Human Rights vis-à-vis Guatemala). Cambodia, another weak state, has resisted and continues to sabotage international intervention. There has been no truth commission, no legitimate trials, and one amnesty. After 1998, despite paying lip-service to the idea of a hybrid court to try Khmer Rouge perpetrators, the process

111. Such depletion of power generally results in the killings or emigration of the skilled professionals-civil servants, teachers, health care providers, economists, and othersnecessary to maintain a modern state.

112. Another marker of the strength of a state is its socioeconomic development, measured by several dimensions such as GDP and the Human Development Index. Under this metric Cambodia, Sierra Leone, and Timor-Leste fall under the category of least developed states; Argentina, Guatemala, and South Africa are middle-income countries while Northern Ireland is viewed as a developed state. However, both Guatemala and South Africa attained middle income status by virtue of the economic strength of their minority populations that held power. 
of creating one has taken years and been marked by strong resistance from the Cambodian government.

Two of the stronger countries, Argentina and South Africa, while taking different pathways, have both had truth commissions and trials or the potential for trials. South Africa developed a unique arrangement for amnesty and trials through its truth commission, while Argentina went through trials followed by periods of amnesty followed by rescission of the amnesty legislation by national courts. While Argentina has utilized the courts extensively over the years to evolve its transitional justice mechanisms, the process in South Africa emerged from the compromise drafted to end apartheid.

Northern Ireland, a constituent part of a strong state, has also followed a unique pathway. There has been no truth commission, no general amnesty, and trials have not been pursued. ${ }^{113}$ However, there have been commissions and investigations by the government of the United Kingdom, decisions by the European Court on Human Rights, victim support programs, and revision of police structures-much of this in a framework for peace crafted by the United Kingdom, the Republic of Ireland, and Northern Ireland. Because this has been seen as an issue primarily for Britain, there has been no direct international intervention.

A clear trend that emerges from the case studies is that either international pressure or a history of a strong judicial system, with respect for the rule of law, is essential to vigorously implement transitional justice measures such as trials and truth commissions. A country that is more developed appears to have greater leeway to institute its own measures. However, weaker states possess the capability of undermining the establishment or work of institutions set up under international auspices. The choice of measures initiated by the international community also appears to be strongly influenced by current trends in transitional justice.

\section{E. International (Multilateral) Intervention}

Only recently has the international community revisited the limits of state sovereignty, raising the question of the conditions under which interna-

113. However, there have been several amnesty-like measures during and since the "Troubles." Major John Clark, Northern Ireland: A Balanced Approach to Amnesty, Reconciliation, and Reintegration, Mit. Rev., Jan.-Feb. 2008, at 37, 43-45; see Daniel F. Mulvilhill, The Legality of the Pardoning of Paramilitaries Under the Early Release Provisions of Northern Ireland's Good Friday Agreement, 34 CORNEL INT'L L. J. 227 (2001). A prisoner release program was a crucial part of the Belfast Agreement. Under this program, over 400 people, both national and unionist, were released; 229 were associated with republican paramilitary organizations, 193 were associated with loyalist groups, and eleven were not aligned with either side. See Northern Ireland Prison Service, News \& Information, available at http://www.niprisonservice.gov.uk. 
tional humanitarian intervention is indicated. ${ }^{114}$ The hesitancy to intervene in another country's affairs is influenced by several issues-sovereignty, a country's own interests, a concern about its own youth fighting in another state $^{115}$ _but, as the NATO involvement in Kosovo and Bosnia revealed, there is more openness to forcibly stopping a country from committing these atrocities. Much of the impetus has come not only from Western countries through the United Nations and its agencies but also through military coalitions. However, we raise the question of how decisions are made to mount an intervention and at what level of intensity. From the perspective of many in the less powerful countries, the impetus lies primarily in the self-interest of the richer, Western countries. ${ }^{116}$ If this is accurate, then the nature of

114. The United Nations recently re-framed the debate on humanitarian intervention with explicit recognition that states have a responsibility to protect their own people as well as those of other states from atrocity crimes. 2005 World Summit Outcome, G.A. Res. 60/1, U.N. GAOR, 60th Sess., Supp. No. 49 (Vol.I) at 3, U.N. Doc. A/60/49 (16 Sep. 2005). The United Nations response has generated discussion among humanitarian groups and international institutions on best practices to follow up the outcomes of the summit. See Andrew Bellamy, Preventing Future Kosovos and Future Rwandas: The Responsibility to Protect After the 2005 Worl. Summit (2006), available at http://www.cceia.org/media/ Bellamy_Paper.pdf (discussing the importance of UN reform and domestic governance in international human rights law).

115. Samantha Power, A Problem From Hell: America and the Age of Genocide (2002).

116. As examples of attitudes towards international justice of those affected by conflict, specifically in Rwanda and the countries of ex-Yugoslavia, see Mr Neighbor, Mr Enemy: Justice And Community in the Aftermath of Mass Violence (Eric Stover \& Harvey M. Weinstein eds., 2004). See also Harvey M. Weinstein, Laurel Fletcher, et al., Justice, Accountability and Social Reconstruction in Bosnia and Herzegovina: An Interview Study of Bosnian Judges and Prosecutors, 18 BERKELEY J. INT'L. L. 102 (1999). Similar statements of ambivalence towards Western justice were made in Iraq in the report Nehal Bhuta, Hanny Megally, Harvey M. Weinstein, Phuong P. Pham, et al. Iraqi Voices: Attitudes Toward Transitional Justice and Social Reconstruction Occasional Paper Series, New York: International Center for Transitional Justice (May 2004), available at http://www.ictj.org/images/content/1/0/108. pdf. The July 2007 Special Report "The Cooling of Hearts": Community Truth-Telling in Acholi-Land from the Justice and Reconciliation Project of the Gulu District NGO Forum and the Liu Institute for Global Issues recognizes the critical importance of local mechanisms and local consultation in effecting transitional justice and reconciliation in Northern Uganda. For cogent observations by academics, see Kenyan legal scholar Makau Mutua, Human Rights: A Political and Cultural Critique (2002), who notes in his analysis of the human rights regime that "the savior is the human rights corpus itself, with the United Nations, Western governments, INGOs, and Western charities as the actual rescuers, redeemers of a benighted world. In reality, however, these institutions are merely fronts. The savior is ultimately asset of culturally based norms and practices that inhere in liberal thought and philosophy." $/ d$. at 11 . He notes that the human rights corpus is "fundamentally Eurocentric" and "promotes a Eurocentric ideal" that results in an "othering process' that imagines the creation of inferior clones, in effect dumb copies of the original." Id. at 11-12. While not directly addressing transitional justice measures, the same critique applies. Rosemary Nagy, Transitional Justice as Global Project: Critical Reflections, 29 THIRD WORLD Q. 275 (2008), comments on "the worrisome tendencies of the international community to impose 'one-size-fits-all', technocratic and decontextualised solutions." She goes on: "Steeped in Western liberalism, and often located outside the area where conflict occurred, transitional justice may be alien and distant 
international intervention may influence the type of transitional mechanism that is selected as well as the timing of that intervention.

With the exceptions of Argentina, Northern Ireland, and South Africa, each of the countries in our study has experienced some type of direct international intervention. The international community has become involved in the affairs of states at two stages: first, intervention during the conflict in an attempt to end the violence and second, intervention in the post-conflict period either to institute transitional justice mechanisms (including the establishment of democratic institutions) and/or in the area of post-conflict reconstruction and infrastructure development. In the first stage, foreign intervention often takes the form of diplomatic initiatives such as trying to mediate or negotiate between opposing sides. This may be followed by peacekeeping operations. In the second stage, the international community, usually through multilateral or bilateral agencies, focuses attention on governance and security as well as on the restoration of a functioning society. We divide our cases into two categories - self-reliant states-where there is no direct international intervention before the transition-and internationallyreliant states-in which other states become directly involved in the internal affairs of the particular country during and after the conflict.

\section{Self-reliant states}

While there has been no direct international intervention in the self-reliant states, international criminal justice has been influential. The work of Spain's Judge Garzón, who indicted former dictators Videla, Massera, and Galteri of Argentina as well as Augusto Pinochet of Chile, helped to pave the way for Argentina to end amnesties and increasingly use the domestic legal system to indict those responsible for the atrocities of the era of dictatorship. ${ }^{117}$ Similarly, in Northern Ireland, international influence has played a role in its evolution. In 1997, US President Bill Clinton sent former Senator George Mitchell to facilitate talks between the Ulster Unionists and Sinn Fein that resulted in the 1998 Belfast Agreement. Additionally, the European Union provided substantial economic incentives to implement the Agreement. Even South Africa was influenced by international pressure through the imposition of sanctions, but South Africans themselves negotiated an end to the apartheid era and the creation of its Truth and Reconciliation Commission.

to those who actually have to live together after atrocity." Similar concerns are found in Helena Cobban, International Courts, Foreicn Poucr 22 (Mar.- Apr. 2006); Rosalind Shaw, Memory Frictions: Localizing the Truth and Reconciliation Commission in Sierra Leone, 1 Int'l J. Transitional Justice 183 (2007). See also Laura Nader \& Ugo Mattel, Plunder: When the Rule of LAW is IlleEAL (2008) (general critique of use of Western legal mechanisms).

117. See generally Naomi Roht-Arriaza, The Pinochet Effect: Transinational Justice in the Age of Human Richts (2005). 
While there have been various critiques of the process, there is no doubt that South Africa found a path that was unique to its cultures and paved the way for new thinking about transitional justice-one where no international intervention was necessary.

\section{International-reliant states}

In contrast to the self-reliant states, Cambodia, Guatemala, Sierra Leone, and Timor-Leste each experienced significant international intervention prior to and throughout the transitional process. The continuity of external involvement in the internal affairs of each country exerted a measurable impact on the development of transitional justice in each context.

We see three levels of international influence in post-conflict interventions: first, a minimalist or indirect kind of involvement, particularly in Argentina but arguably in South Africa as well; second, a facilitative approach as in Northern Ireland; and finally, an active and direct involvement either with troops or United Nations participation, in Cambodia, Guatemala, Sierra Leone, and Timor-Leste.

Table Two summarizes the international interventions in our selected countries:

The table illustrates that where the international community is not heavily involved during the conflict, there is not heavy post-conflict investment.

The use of transitional justice mechanisms in weak states appears to be heavily influenced by the will of the international community. Guatemala and Sierra Leone accepted international influence. In Cambodia, the prolonged negotiations to establish a tribunal suggest that the government of Cambodia is not only resistant to the idea but has chosen a method of resistance to international pressure that is designed to preserve its sovereignty while paying lip service to the will of the world community. ${ }^{118}$ Finally, Timor-Leste, a territory that was abandoned by the international community and then turned into a virtual UN colony, has seen attempts to offer international legal justice subverted and other elements of transitional justice constrained.

\section{F. Government Commitment to Transitional Justice}

Political commitment to addressing mass violence emerged as a factor that influences the timing, sequencing, content, and strength of measures to promote social reconstruction. The degree of support offered by political

118. In essence, while some people in Cambodia see trials as essential to combat impunity and restore history, the government has not embraced this vision fully. For information on the government response to human rights organizations in Cambodia, see U.S. Dep't of State, 2006 Country Reports on Human Rights Practices: Cambodia (2006). 
Table 2

International (Multilateral) Intervention

\begin{tabular}{|c|c|c|c|c|}
\hline \multirow[b]{3}{*}{ Argentina } & \multicolumn{2}{|c|}{ Conflict } & \multicolumn{2}{|c|}{ Post-Conflict } \\
\hline & Diplomatic & Military & $\begin{array}{l}\text { Admin/Security/ } \\
\text { Reconstruction }\end{array}$ & $\begin{array}{c}\text { Transitional } \\
\text { Justice }\end{array}$ \\
\hline & 0 & 0 & 0 & Indirect \\
\hline Cambodia & $x$ & 0 & $x$ & $x$ \\
\hline Guatemala & $x$ & 0 & 0 & Indirect \\
\hline Northern Ireland & $x$ & 0 & 0 & 0 \\
\hline Sierra Leone & $x$ & $x$ & $x$ & $\mathrm{x}$ \\
\hline South Africa & $x$ & 0 & 0 & 0 \\
\hline Timor-Leste & $x$ & $x$ & $x$ & $x$ \\
\hline
\end{tabular}

parties towards creating a functioning state with adherence to democratic principles and the rule of law contributes to the success of any state-sponsored response to violence.

In both South Africa and Northern Ireland, governments have respected the negotiated contours of the commitment to address the crimes of the past. In neither case have these crimes been forgotten, but the parties have expressed a preference for public acknowledgment of past horrors rather than individual criminal accountability. ${ }^{119}$ And in neither country has there been political initiative to renegotiate this deal. Subsequent political exigencies in each country may even diminish political appetite to seek more aggressive accountability measures. ${ }^{20}$ In short, these governments adopted transitional justice initiatives where retribution was not the most salient feature, and they

119. In Northern Ireland, most prosecutions have focused on paramilitaries with little accountability for government officials involved in the violence. Angela Hegarty, Dealing with the Past: Government of Memory: Public Inquiries and the Limits of Justice in Northern Ireland, 26 FordHAM INT'L L. J. 1148, 1149-50 (2003). In South Africa, there have been few prosecutions. See supra note 36 , and accompanying text.

120. Stalled progress toward implementing the Agreement in Northern Ireland kept political focus on fulfilling the basic promise rather than a wholesale renegotiation of the settlement. Bell, supra note 49, at 1095. In South Africa, with the priority of the government on building the country's GDP, the urgency to maintain an attractive business climate to generate economic development may overwhelm any desire to ferret out apartheid wrongdoers who did not apply for or did not receive amnesty and impose criminal sanctions. While there are no direct policy statements to this effect, the government's response to the question of reparations from businesses that benefited during the apartheid era suggests such a motivation. In response to the class action lawsuit filed in the United States by four separate groups of apartheid victims under the Alien Tort Claims Act, a government spokesperson stated: "not settling the matter in South Africa has profound implications for the country ... for instance, for the assessment of (its) risk profile, investment, and job creation." See Sapa Terreblanche \& Christelle Terreblanche, State Not Backing Tutu Support for Lawsuits, CAPE TImEs, 2 Feb. 2004, available at http:// www.int.iol.co.za/general/news/newsprint.php?art_id=vn20040202024037570C29571 9\&sf. 
do not appear eager to revisit the basic political arrangement that settled how these societies would address the crimes of the past.

In contrast to Northern Ireland and South Africa, the experience in Argentina, Cambodia, and Guatemala points to greater reluctance of those governments to address the crimes committed during the conflicts that beset those countries, at least in the immediate aftermath of the violence. In each case, governing parties have been ambivalent toward or uncommitted to fully exposing the horrors of the past and acknowledging the harms suffered by victims. However, even those countries with initially reluctant political leaders have experienced reforms over time that have accommodated (but not fully satisfied) the demands of victims.

In Sierra Leone and Timor-Leste there has been insufficient time since the political transfer of power to democratically-elected governments to enable a considered evaluation of the commitment of governing parties to transitional justice. ${ }^{121}$ In both countries, transitional authorities approved UN-sponsored tribunals and national truth commissions prior to national elections. Political parties appear to support the operation of these mechanisms, though they are slow to implement fully the mandates of these institutions. ${ }^{122}$

Northern Ireland and South Africa are the countries with the most consistent political support for the brokered political agreement that ended the violence in those countries and created the transitional justice framework that would follow. Yet these measures are modest compared to interventions in other cases that have sought to identify and sanction (morally or legally) individuals or sectors responsible for the violence or repression. In fact, in Northern Ireland, the Belfast Agreement called for structural changes and power-sharing without any specifically-mandated accountability measures such as a truth commission or trials. ${ }^{123}$ South Africa emphasized truth seeking and restorative justice over sanctioning wrongdoers, and the total applications for amnesty to the TRC is modest by estimates of the total number of perpetrators. ${ }^{124}$

Successive governments in Argentina, Cambodia, and Guatemala have returned repeatedly to the thorny issue of how to address past crimes. Political will for the more direct, forceful response of trials has waxed and waned

121. Timor-Leste declared independence in 2002, and the first elections under the new constitution took place in April 2007. In Sierra Leone, parliamentary elections occurred in 2002 and the first president was elected in 2006.

122. For example, the Timor-Leste government bowed to Indonesian pressure and did not release the final report from the joint Commission on Peace and Friendship. The Commission for Reception, Truth and Reconciliation (CAVR) is based in Timor-Leste and started in 2002, while the Joint Commission is the result of a bilateral effort in 2005. Further, the President stalled public release of the Truth Commission report even though it was widely available on the internet.

123. See Agreement, supra note 51.

124. HAYNeR, supra note 24 , at $42-43$. 
in these countries. However, over time we see that political commitment to transitional justice has increased. Argentina and Guatemala, under the leadership of left and right-leaning political parties, respectively, have initiated new measures to redress, symbolically if not legally, the crimes of the past. Cambodia's government, while ambivalent, has set a course to prosecute those most responsible for the genocide. In Guatemala and Cambodia, in the immediate aftermath of the violence, there was the legal opportunity for prosecutions, but no political appetite to institute proceedings. In the case of Argentina, after the initial push for prosecutions, a backlash from the military threatened the return of democracy, and therefore, efforts at accountability slowed substantially but have never ceased. Only in the cases of Sierra Leone and Timor-Leste, the most recent countries to emerge from internal conflict, have new governments established criminal tribunals as well as truth commission in the immediate aftermath to thrust justice center stage in the country's effort to rebuild. ${ }^{125}$ These data suggest that early vigorous engagement with the past through criminal trials is the exception rather than the norm and that political commitment to modest reforms leads to more consistent follow through by governments.

\section{G. Post-transition Structural Reforms}

One conventional justification for transitional justice holds that the symbolic and instrumental value of trials or other forms of accountability lies in the power of these special measures to signal a break with the policies and politics of the past that led to the violence. ${ }^{126}$ Structural reforms go deeperbeyond the criminal acts of individuals-and seek to resolve or defuse the social, political, and/or economic disputes that ignited the initial conflict. We examined the case studies to identify the measures, if any, governments initiated after the end of bloodshed to address the underlying factors that contributed to the violence. We also reviewed the significant legal, political, social, and economic events that have occurred in each country since the onset of the transition. Across our case studies there is considerable variation in the length of the post-transition period as well as in measures undertaken to remedy the root causes of the conflicts. As discussed above,

125. However, the governments in Sierra Leone and Timor-Leste face enormous challenges to (re)build their countries and may find themselves politically constrained in their ability to maintain their commitment to transitional justice following the completion of the truth commissions and/or trials interventions they have initiated to date.

126. See Jon Elster, Closing the Books: Transitional Justice in a Historical Perspective (2004); Gary Bass, Stay the Hand of Vengeance: The Poltics of War Crimes Tribunals (1999); Aryen Neier, War Crimes: Brutality, Genocide, Terror, and the Struggle for Justice (1998); Hayner, supta note 24. 
for purposes of discussion we have grouped our case studies according to the defining nature of the conflict, i.e., ideological, identity-based, separatist, and socio-economic, noting that in any given case, these categories may overlap to some degree.

Reviewing the transitional justice measures adopted in our case studies against the nature of the underlying conflict yields interesting findings. The ideologically-based conflicts of Argentina and Cambodia have largely been resolved, yet each country has adopted different approaches to facing up to the past. Argentina had a truth commission, and the government responded over time to constant pressure from civil society to overcome legal and political barriers for domestic criminal trials. In Cambodia, there has been no truth commission and the government has shown no real appetite for trials. In contrast, in Guatemala, the conflict was driven by a blend of political demands for redistribution of power and resources to the indigenous majority, which has been only partially addressed. The country's efforts to acknowledge the civil war have been half-hearted as well. The truth commission report did little to foster consensus and there have been few trials.

The identity-based and separatist/identity-based conflicts in South Africa, Timor-Leste, and Northern Ireland also yield mixed results in terms of the types of transitional justice measures adopted. Timor-Leste had both a truth commission and criminal prosecutions under international tutelage. South Africa and Northern Ireland pursued home-grown transitional justice; South Africa's truth-for-justice political swap privileged reconciliation and publication of the crimes over retributive measures, while in Northern Ireland traditional truth-telling and accountability measures have been subordinated to a political compact that holds the promise of democratic self-rule in a state in which minority rights will be respected. Finally, in Sierra Leone, where socio-economic struggle may be said to have fueled the conflict, the nation has created a truth commission as well as criminal prosecutionsboth with UN assistance.

Our data suggest that resolution of the underlying conflict may be a necessary condition for political stability-in none of these countries has open conflict resumed since the transitions. However, the degree of resolution does not appear to be linked to the nature of the conflict or the type of mechanisms implemented to address the past. The variation in the tools used to address the past among countries within the same category of conflict (ideological, separatist, etc.) leaves no clear pattern. ${ }^{127}$ Whatever the source of the conflict-ideological, identity-based, separatist, or socioeconomic-it appears that it is the commitment to and implementation of structural change,

127. We note that political stability may be influenced as well by forces beyond the control of individual governments, e.g., commodity price fluctuations, regional instability, transnational crime networks, etc. 
more than any single process such as a trial or a truth commission, which sets the country on the road to resolution.

\section{H. Timing}

The ability of a country to address structural aspects of the violence is related to the length of time that a country has had to undertake such reforms. It has been more than a decade since the end of the conflict or repression in Argentina, Guatemala, Northern Ireland, and South Africa. The reign of the Khmer Rouge ended over thirty years ago, but it is only nine years since the Khmer Rouge leadership surrendered its ambitions to power. Sierra Leone and Timor-Leste are each less than a decade into their transitions. In examining those case studies in which countries have experienced over a decade since the conclusion of the conflict or return to democracy, there appears within each country a shift in transitional justice policies at approximately six to eight years after the onset of the transition. In each of these countries except Cambodia, the government initiated measures during this period to address the needs of victims of the repression, often through monetary compensation, for the harm inflicted by the state.

Importantly, all countries modified their original transitional justice responses after a moderate period of time. Most of the countries with a decade or more of transition also are countries in which truth commissions constituted the primary response to the past--Argentina, Guatemala, and South Africa. Northern Ireland and Cambodia are exceptions. Yet there is no clear link between the type of transitional justice mechanism adopted and the delayed outreach to victims. However, in every country but Cambodia, the alteration in transitional justice policy aimed to satisfy the needs of victims. Given the heightened rhetoric regarding the need for a country in transition to embark on a program of transitional justice to redress the injuries inflicted on victims, it is significant that we see countries taking modest steps toward fulfilling the spirit, if not the letter, of the commitments originally made to victims at the start of the transition period.

\section{DISCUSSION}

Our findings reveal the complexities that underlie transitional justice. While it would be useful to have a series of tried and true measures that could be utilized in all countries faced with post-conflict justice and social reconstruction, sadly that is not the case. These states live amidst a maelstrom of conflicting goals, motivations, and realities. While international criminal justice in the form of international tribunals offers one mechanism of re- 
sponse, and truth commissions another, the choice of legal response must be carefully weighed and implemented in conjunction with other forms of intervention. How then can we best make a determination of the most appropriate path to take?

Our findings confirm that the level of economic development of a country has important bearing on the ability of countries to implement transitional justice measures. Argentina, Northern Ireland, and South Africa, with advanced economies (South Africa, despite low per capita income, boasts a substantial industrial and commercial infrastructure) and well-developed legal systems, crafted a domestic response to address the wrongs of the past. The experience of these countries is markedly different from the lesser developed countries of Cambodia, Guatemala, Sierra Leone, and Timor-Leste. However, we found no relationship between the variability in the nature and length of the conflict and how it was concluded (negotiation versus military intervention), on the one hand, and the way in which countries utilized transitional justice mechanisms, on the other. Importantly, we did find that if the international community was involved actively in the termination of the conflict, a relationship exists with the mechanisms of transitional justice established post-conflict.

Culture and traditions shaped the response of a country to its past period of repression or mass violence. While we did not directly track the relationship of cultural practice to transitional justice mechanisms, our analysis indicates a dynamic relationship among the racial, ethnic, and religious identity of those persecuted, their political power, and the social values to which political leaders could appeal in crafting the state's response to the violence. In countries with strong indigenous cultures such as Guatemala, Sierra Leone, South Africa, and Timor-Leste, traditional practices and beliefs may influence the choice and/or perceived legitimacy of the usual transitional justice practices. For example, it is not surprising that in both South Africa and Timor-Leste, political leaders chose to emphasize the continuity with indigenous values and culture in the selection and implementation of their truth commissions. Similarly, the findings confirm our hypothesis that international intervention leaves an indelible mark on the nature of the transitional justice response adopted by a country. And finally, we identified a clear and strong link between the strength of a country's legal system based on adherence to Western models of justice and how transitional justice is perceived.

It has been a common trope that transitional justice allows countries to "start over" by settling accounts with the past. ${ }^{128}$ However, the past seeps

128. An example of this assumption can be found in the titles of various books on transitional justice: Trudy Govier, Taking Wrongs Seriousiy: Acknowledgment, Reconciliation, and The Politics of Sustainable Peace (2006); Elster, supra note 126; Burying the Past: Making Peace and Dolng Justice After Civil Conflict (Niel Biggar ed., 2003); Andrew Rigby, Justice and Reconcliation: After the Violence (2001). 
into transitional justice-whether by design or as an unintended unwelcome intruder. The strength of a country's legal and political institutions and its experience of colonialism exert important influence over the way in which transitional justice measures have developed. Our case studies reveal a division along virtually all of the factors identified between Argentina, Northern Ireland, and South Africa-self-reliant transitional justice states-on the one hand and Cambodia, Guatemala, Sierra Leone, and Timor-Lesteinternational-reliant transitional justice states-on the other. The fault line between the two groups severs along deeply ingrained political, economic, and legal structures that provide the framework on which choices regarding transitional justice occur.

The two key factors that appear in all self-reliant transitional justice states are strong rule of law and little or no international intervention in resolving their conflicts or in shaping the transition that followed. Conversely, in international-reliant transitional justice states, the rule of law is weak and international intervention played a large role in concluding the fighting and in initiating an official response to the past. In the following discussion, we seek to explain how the factors that emerged from our analysis contribute to the patterns we identified. We suggest that the dynamic interaction between: (1) a country's capacity for autonomous resolution of conflict and self-determination with regard to transitional justice mechanisms, (2) the legacy of colonialism, and (3) the cultures and traditions of a country explain the divergence within the case studies. We suggest further that these are the principal factors that influence the choice and timing of trials and truth commissions, the primary transitional justice mechanisms that we examined. We then offer further observations about the significance of our explanatory model for the field of transitional justice.

\section{A. Contextual Dynamics of Transitional Justice}

Our findings suggest that multiple factors influence the nature of transitional justice mechanisms selected by any particular country and the manner in which such interventions unfold. One possible critique of transitional justice policy and its implementation is that it is usually ahistorical or decontextualized. Debates around such issues as truth versus justice, trials versus truth commissions, and remembering versus forgetting frequently treat these concepts as abstract and universal principles. These findings point us in new directions when considering the possibilities and limits of transitional justice. In our earlier work, we proposed an ecological approach to understanding the measures needed for societies to rebuild in the aftermath of mass violence. ${ }^{129}$ This approach emphasized that legal justice, whether as criminal

129. Fletcher \& Weinstein, supra note 2 , at 621-35. 
prosecutions or truth commissions, was but one component of needed post-conflict interventions and that justice initiatives should respond to and be coordinated with other interventions such as rebuilding infrastructure, psycho-social programs, economic development, political reform, etc. ${ }^{130}$

Our current findings regarding these seven case studies indicate that history and current context exert a profound influence on the ability of a society to respond to state repression or mass violence. Thus this analysis leads us to conclude that policymakers and scholars need to develop an appreciation for the ways in which a country's inheritance of its legal system, culture, and democratic traditions as well as its social and political institutions and history of sovereignty interact with each other and the country's contemporary political climate to shape the form and pace of transitional justice efforts. Perhaps the most important finding from this analysis is that transitional justice mechanisms offered in a mechanical manner will be less successful if context is ignored.

In the rush to advance justice and reckon with the past, international diplomats, NGOs, representatives of international organizations, and scholars may overlook the limitations and history of the context in which these interventions will unfold. While the United Nations may promote early accountability as a universal value, this is not born out in practice and we question the viability and desirability of this norm. ${ }^{131}$ Weak democratic structures and legal institutions in Cambodia, Sierra Leone, and Timor-Leste pose considerable challenges for transitional justice initiatives in those countries to contribute to long-term societal reconstruction. For countries with strong domestic institutions, the international stakeholders may similarly have unrealistic expectations for what a country will do to address the horrors of the past and over what period of time. International support for accountability for state-sponsored crimes during the dictatorship has been important in Argentina, but domestic civil society has championed reversal of the amnesty laws and paved the way for domestic criminal trials.

The point is that there is no tabula rasa society upon which transitional justice is inscribed. Context matters and it matters considerably. Accountability for crimes and an official and full narration of the repression or violence and its effects have gained considerable support as critical measures to enable countries to put the past behind and rebuild. But we need to look beyond moral and legal exhortations to implement transitional justice measures and ascertain what is most needed to help communities regenerate and when. Factors such as the strength of political and legal institutions and culture are critical to such an analysis yet have been paid too little attention by promoters of transitional justice.

130. Id.

131. See Report of the Secretary-General, The Rule of Law ano Transitional Justice in Conflict and Post-Conflict Societies, U.N. Doc. S/2004/616 (2004). 
Building new institutions often will be necessary, yet we must be aware that these efforts unfold in a historical context. We found that in weak states with inadequate rule of law, international intervention brings with it assumptions about the form and content of transitional justice mechanisms. The prevailing policy options are criminal prosecutions and truth commissions (sometimes simultaneously). This has led to an almost prescriptive approach to "best practices" in dealing with the past. This raises questions about whether there is any room for approaches that build on local culture and mechanisms that are consistent with international human rights norms. There are no empirical data to substantiate any particular approach but critiques of the effects of implemented programs over the long-term indicate that a gap exists between local needs and priorities and the specific mechanisms put into place. For transitional justice to model fairness and justice, is it necessary to put into place a model that mimics Western legal mechanisms? We suggest that the goal of transitional justice is to initiate a process that allows for a dynamic interaction between the society's cultures and practices to develop responses that reflect what is unique in that society. This allows for the possibility that new forms of transitional justice may develop. We must caution, however, that what is local must not be subverted by the political as in the case of Rwanda. ${ }^{132}$

Addressing institutional imbalances in turn requires political leadership. And the degree of political commitment to address the injustices of the past-criminal acts as well as correcting systemic inequities-will shape the pace and form of transitional justice. Further, the national political leadership provides "home-grown" impetus for change for which international intervention is no substitute. Where governing parties are ambivalent or opposed to international intervention to institute trials or truth commissions, implementation of transitional justice will be slowed. The ability of transitional justice measures to contribute to the rebuilding of societies after repression or mass atrocities will be determined by a number of factors; our analysis points to some of the most salient. ${ }^{133}$

\section{B. Capacity for Autonomous Resolution}

We found in our case studies that the self-reliant transitional justice states share the common features (relative to the other case studies) of strong

132. See Lars Waldorf, Mass Justice for Mass Atrocity: Rethinking Local Justice as Transitional Justice, 79 Temp. L. Rev. 1 (2006). Waldorf suggests that the gacaca process largely has been used by the Rwandan government to pursue its political objectives.

133. While we have not addressed the role of civil society directly, the degree to which nongovernmental organizations engage with the political process can, in turn, influence government policy. Our analysis focuses on state responses; however, the influence of civil society post conflict deserves further exploration. 
democratic institutions, the rule of law, and political parties committed to a negotiated settlement. These attributes allow countries to chart their own course of transitional justice rather than having the international community script their future. The implications of autonomy are profound and reverberate across economic, political, legal, and social dimensions.

The underlying factors that contribute to these features-wealth, legitimacy of legal institutions, political consensus-also produce benefits that support stable societies in other dimensions-jobs, public confidence in political processes, and social stability. Similarly the synergies among these factors impact the pace and influence of transitional justice interventions in each country.

The trilogy of countries that pursued purely domestic programs to address the past is composed of "strong" states, which are aided by more advanced economies. Perhaps, not surprisingly, wealthier countries in our case studies had stronger legal institutions and greater political power to settle the conflict internally. Similarly, in these countries the state had the capacity to provide the basic social and political infrastructure needed to support stable societies in the aftermath of conflict. As a result, political violence was largely contained, enabling the country to attend to the future rather than having to relive or continue to negotiate a new political compact to end the repression or mass violence..$^{134}$ In contrast, international-reliant transitional justice countries are lesser developed and all battle corruption and/or are struggling to establish a functioning government, provide jobs, and fulfill the basic social contract between citizen and state. These countries must face challenges common to all lesser developed countries and, in addition, rebuild the social fabric of communities.

The legitimacy of state institutions in self-reliant transitional justice countries may enable the populace to trust that post-conflict governments will make good on their commitments to address the wrongs of the past. The international-reliant countries, in contrast, have weak legal, social, and political institutions and greater international involvement. It may be that the lack of legitimacy of domestic institutional structures required for social stability helps to push these countries toward the United Nations and other international institutions to provide an adequate response to past abuses. Further, in weak states, a power imbalance between the military and civilian government that contributed to the conflict may pose significant, post-conflict challenges for governments attempting to establish a political, economic, legal, and social environment in which communities are able to rebuild.

134. Societal violence (as opposed to political violence) may continue or increase after the conclusion of the conflict, even in strong states. The high crime rates in South Africa-a strong state-attest to stress on social networks brought on by lack of economic opportunity, continued and striking disparities in distribution of such resources as education and health care, and the effects of the HIV/AIDs pandemic. 
It is striking that those with the strongest courts used them the leastNorthern Ireland and South Africa. While Argentina turned to its robust legal system initially, political backlash and military pressure combined to forestall criminal prosecutions for the next twenty years. Virtually all countries we studied with weak courts established a program to prosecute the crimes of the past with direct involvement of the United Nations-Cambodia, Sierra Leone, Timor-Leste-but with difficulty. In Guatemala, the United Nations played a relatively limited role. The absence of provisions for internationalized criminal trials in the peace agreement in Guatemala may also reflect the lack of international consensus and political will to impose accountability at that time; truth commissions were the accepted alternative to trials.

This suggests that the capacity to conduct trials is not predictive of whether they will occur. Reliance on the international community to ensure legal accountability in Cambodia, Sierra Leone, and Timor-Leste also raises the importance of linking internationally-sponsored efforts to conduct criminal trials to efforts to strengthen the domestic rule of law. Integrating these two policy thrusts will help protect against a gap emerging between local and international justice which may become suffused with accusations that international-sponsored "justice" is (yet) another instance of foreign or Western imposition. The link between the strength of the rule of law and the ability of a country to chart an autonomous path of transition is striking. It points to the need to examine the relationship between transitional justice interventions and enhancing domestic capacity.

Similarly, our findings suggest that the context of the political negotiations that conclude the conflict, and the level of domestic political support for retributive justice, is a better predictor than the strength of legal institutions of whether and when a country will pursue criminal accountability as a form of transitional justice. Contexts in which domestic political leadership is capable of reaching a negotiated transfer of power without significant international assistance indicates that political institutions and parties in these countries are sufficiently developed to manage dissent largely non-violently. Thus the self-reliant transitional justice countries may forego immediate trials-but not foreswear transitional justice. When compared to the mixed results of the rushed responses in internationally-reliant countries, self-reliant countries seem to have benefited from proceeding slowly, with greater internal political stability and support.

The divide between self-reliant and international-reliant countries should give pause to those who advocate for a universal approach to justice-in particular in the form of criminal trials-in the immediate aftermath of a period of repression or mass violence. In particular in recent years, we see a tortoise versus hare approach to the retributive measures countries adopt to address the past. And the "tortoises" - with greater internal capacity for governance and a political, if not social, consensus about how to and how much to 
delineate responsibility for past abuses-are charting a clearer, though more modest, course ahead than the deceptively nimble "hares." The latter rush to judgment with the heavy hand of the international community nudging them along the path towards a foreign conception of accountability.

\section{Colonialism}

Our findings point to the influence of colonialism on the choice and implementation of transitional justice mechanisms. Its impact is felt across all dimensions we studied-political, legal, social, and economic, but not equally or in all cases. Again, we see a divide between the self-reliant and internationally-reliant transitional justice countries. For example, Argentina and Cambodia are both countries that experienced colonial rule; each is conducting criminal trials of abuses that occurred thirty years after each country "transitioned" from the repressive or genocidal rulers. Yet the legitimacy of the processes varies greatly -in Argentina the trials are the culmination of a thirty-year battle waged by civil society to hold military leaders accountable. In contrast, in Cambodia the international community has championed criminal trials, which have been met with deep ambivalence within the government and without any clear indication of popular support. What accounts for the differences?

Our findings point to the unforeseen consequences of the inter-relationship between the legacy of colonialism, international intervention, and the implementation of transitional justice initiatives. In countries that have not "overcome" the imprint of a colonial sponsor to establish strong indigenous public institutions-Cambodia, Guatemala, Sierra Leone, and Timor-Lestetransitional justice initiatives are initiated under the aegis of international sponsorship. Under the auspices of the United Nations, international assumptions about what countries need to move forward take shape in contexts that bear the grim scars of colonial histories-the broken promises of societal advancement that subjugation to the colonial power was supposed to bring. In these countries, the shiny new "penny" of transitional justice offered by the international community may be easily tarnished by skepticism about the benefits of foreign involvement in the internal affairs of that particular country. Transitional justice measures face numerous difficulties, yet the resistances and distortions of the processes in the weak states may be attributed in part to the very fact of international involvement. For example, the Cambodian government's resistance to the United Nations insistence on a majority of international judges to the Extraordinary Chambers gains purchase as an assertion of Cambodian sovereignty and national pride. Thus governments reluctant to engage the past, or seeking to shield their own members from having to account for their own violations, as in Rwanda, have a ready foil 
with which to deflect international pressure to establish justice measures that are impartial and fair.

At the same time, weak states are vulnerable to giving international interveners too free a hand in crafting transitional justice measures. We speculate that in international-reliant countries, there is a path dependency with regard to how national governments negotiate the ostensible benefits of assistance that transitional justice initiatives are thought to confer. In these instances, countries may become passive receptacles of the current "best practices" with insufficient regard to the need to tailor these interventions to local culture and context. And social and economic schisms between the government elite, who negotiate with representatives of international organizations responsible for transitional justice, and the victims of the violence and the populations directly affected may further obscure the gap between a universal approach and local needs. The apparent presumption among weak state governments, that the international community brings the latest and best approaches to tackling thorny issues like accountability for mass violence, echoes the logic of colonial intervention which has split the governing elite from the rest of society. Disenchantment with transitional justice measures-whether trials or truth commissions-percolates up from below, as in Sierra Leone. ${ }^{135}$ The danger is that the advocates, diplomats, and representatives of international organizations will serenade officials in weak states too effectively about the promises of trials and truth commissions; the international voices calling for governments to address the past may drown out the local voices - which may not yet be audible or strong enough to carry a discernible tune.

Despite the danger that the international runs rough-shod over the local, we also have to consider what might happen in weak states in the absence of international interventions to promote transitional justice. Under United Nations auspices, the international community may exert political pressure on countries to address the crimes of the past, but are we doing so in way that perpetuates negative perceptions and consequences of colonialism? On the other hand, there are moral, if not legal, implications of leaving wartorn countries to determine what, if anything, they should do to redress the crimes of the past. The push toward accountability is driven by the belief that atrocity crimes need to be punished, victims acknowledged, and that the failure to act erodes the international rule of law. The problem is that our findings indicate that the international community has not done a very good job of implementing transitional justice measures, an issue on which our data shed additional light.

135. Shaw, supra note 3 . 


\section{Transitional Justice Measures}

Our findings indicate that criminal prosecutions are the exception rather than the norm as a transitional justice response. However, the dynamic nature of a country's response to past repression or mass violence, and the need to pay greater attention to changes over time in political leadership, structure, and national culture, must be accounted for when implementing transitional justice. Comparing the response of countries in the first few years following the end of repression or mass violence, there is a range of possible responses. Argentina and Guatemala are states that attempted and retracted from trials (Argentina) or opted for truth commissions rather than trials (Guatemala). Northern Ireland and South Africa crafted responses that acknowledged past wrongs but emphasized structural measures or a restorative justice approach. On the other hand, Cambodia, Sierra Leone, and Timor-Leste are countries that, with considerable international involvement, initiated criminal trials. One possible explanation for this variation is the emergence of an international consensus that atrocity crimes should not go unpunished. As a corollary, blanket amnesties are rejected as a necessary compromise to purchase peace. However, new governments such as Cambodia may be reluctant to follow this trend because the new regime incorporates former enemies into the government. Thus political leadership and commitment to confront the past may become distorted by pressure to shield those in power from owning up to their responsibility for past abuses.

Conversely, negotiated settlements between parties that each has blood on their hands do not necessarily foreclose accountability, as Northern Ireland and South Africa indicate. This suggests that an international norm towards accountability is qualified by the political power of stronger states to craft alternate responses. These states turn to truth commissions or similar inquests, which offer more flexible methods of documenting and acknowledging past crimes and human rights violations. Leaving aside objections about selective prosecutions and a lack of international even-handedness, truth commissions may make an important contribution to rebuilding countries in transition. However, the effectiveness of truth-seeking alternatives to criminal prosecutions in promoting stability is dependent upon the political will to support public debate and dialogue regarding the official account that emerges and the follow-through of governments in implementing their recommendations.

Critical too is the political commitment to undertake structural reforms that go to the heart of the conflict-land reform and resource distribution; racial, ethnic, and gender discrimination; political and social exclusion; etc. Often resistance to such measures within governments, and within societies, undermines the ability of countries to overcome the burdens of history. The challenge is for weak states to secure sustained financial support over the 
decades needed to strengthen the rule of law and democratic governance. International intervention may support such efforts, but ultimately that support is no substitute for a national consensus to confront past inequities and for the political leadership to do so.

Our findings indicate that state responses to past repression or mass violence are dynamic rather than static. This leads us to consider the importance of time and the need to support opportunities for evolutionary change in how countries confront the past. Argentina is a case in point-few would have predicted in 1985, when the new government halted criminal prosecutions with amnesty laws, that trials would resume decades later in a political context in which criminal accountability for military crimes would not threaten Argentine democracy. The rush to select and implement transitional justice in the immediate aftermath of violence or repression appears to lead to hasty decisions about which of the dominant transitional justice models should be imposed. Rather, the more salient question is what the affected society wants in the immediate aftermath and how can the response be tailored to the particular cultural, social, and economic contexts.

Domestic political support for any plan is essential for its success. However, our findings suggest that political conditions change and that initial reluctance or resistance to addressing the past may soften over time. Dramatic changes have taken place in Argentina and Cambodia to initiate criminal prosecutions (only time will tell whether the international involvement in trials in Cambodia will promote social reconstruction there). The trend is for immediate criminal trials and truth commissions (perhaps even simultaneously) where the international community is involved and it is not yet clear whether this rush to judgment and acknowledgment benefits victims. Victims may be sidelined initially regardless of the type of state response, but governments do implement new policies to address the needs of victims after a modest (six to eight year) period of "settling." This suggests that identity formation and group action by victims to the conflict, if not inevitable, emerges naturally, and may become an influential contributor to the long-term transitional justice process.

International and national leaders negotiating a country's return to democracy grapple with broad political questions revolving around how to secure the cessation of hostilities and the transfer of power consistent with commitments to justice. The voices of victims and the needs of local communities are among the concerns addressed by the parties but may not assume the highest priority. Nevertheless, in the subsequent years, local priorities may assert themselves--undermining the claimed success of transitional justice or insisting on particular types of action. Open-ended processes of reckoning that develop over time may not only be inevitable, but welcome. In fact, conceiving of transitional justice as an ongoing process of transformation that may be initiated by a set of interventions rather than defined as these 
interventions may be more useful. Initiating any particular type of response, however challenging, pales in comparison to the dynamic and diffuse effects of such interventions; these must be studied and revisited over time lest unintended consequences undermine the goals for social rebuilding.

\section{CONCLUSIONS}

In this paper, we have tried to shed more light on the questions and assumptions that drive transitional justice strategies. We have looked retrospectively at the evolution of transitional justice in seven representative countries. We are aware that some may fault our choice of cases, the foci of our analyses, or the patterns of response that we have identified. However, by utilizing an historical perspective and examining the events that emerged in these countries, we are trying to advance the debates about transitional justice and appropriate responses in post-conflict societies and expand our scope of understanding. The eight factors that influence country response postconflict strongly support our initial hypotheses about what matters ultimately in achieving some resolution with the past. At the end we are left with tensions that require further discussion and debate among policymakers, diplomats, and advocates. If universal principles of accountability are to be applied, then at what point do we assess the fairness of transitional justice in these countries? Further, if a state is on its way to developing the rule of law and democratic governance, does the international community give it time to build these institutions and begin its own processes of transitional justice when ready? is there an accurate method of assessing local attitudes toward justice and if so, who should do the assessment? If those attitudes are against the use of any specific mechanism, e.g., trials or truth commissions, can the international community accept that decision?

These tensions are exemplified by the current disagreements around the appropriate response to the Lord's Resistance Army in Northern Uganda and include the debate about peace versus justice; the role of an international court and local preference; the utilization of cultural alternatives to Western law (common or civil law); the idea of universal jurisdiction; the question of timing and sequence of retributive justice; the application of international humanitarian law and human rights law; and finally, the question of state sovereignty and prerogatives. However, our findings suggest that in those states where there is strong rule of law, democracy, and a negotiated political settlement, the global community will respect the decisions of these governments to choose the substance, timing, and sequencing of transitional justice interventions. Consequently, the ability of states to control their own processes of transitional justice will be heavily influenced by geopolitical realities. This raises the question of whether universal principles can be enforced and whether that is even a desired goal. 
It is apparent from our findings that we must separate out justice from the underlying structural and social causes that led to the violence. Our analysis indicates that while it has been expedient to institute trials (local or international) and/or truth commissions, neither mechanism is guaranteed to resolve these underlying factors. One cannot assume that combating impunity or acknowledging the role of those who contributed to the violence changes the underlying socio-structural conditions that fostered the conflict. Attention to the underlying socioeconomic disparities and inequalities in the country, in conjunction with structural change in the way that the country is governed, may be the most important first steps in developing an appropriate response to perpetrators of violence. ${ }^{136}$ Without strong rule of law, democratic traditions, and economic prosperity, any intervention will be problematic. Precipitate accountability measures that are virtually prescribed by the international community may lead nowhere in terms of "dealing with the past." As we have noted, political commitment on the part of the governing party to address the underlying issues, as well as ownership and control over those processes, is key to acceptance of change. However, change is slow and incremental as societies transform and evolve. This suggests that international support for development of the necessary long-term changes may be the logical first step in a post-conflict society. Allowing evolutionary processes to develop is critical because early and hasty interventions based on narrow models may not connect with the societies' needs for structural reform. The interventions create their own noise and may inhibit home grown solutions.

What is the connection between accountability, truth-seeking, and promoting political change in a country? Timing and sequencing are critical variables. We do not mean to suggest that official reckoning should be ignored or put off to some distant future. Our concern is with a premature, reflexive response to initiate trials or a truth commission. It is quite possible to attend first to structural change while addressing issues of retributive justice (assuming that retributive justice is a desired goal). Two possibilities emerge. First, attend to the development of a judicial/policing system that is transparent and legitimate. Then as these structures emerge, collaboration between local judiciary, lawyers, and international stakeholders would assess retributive measures. Attention would be paid to the expressed needs and wishes of the people through the application of population-based measures of assessment. At the same time, the promotion of and support

136. Other scholars have noted the distinction between the ability of criminal trials versus structural changes to promote societal transformation in the aftermath of mass violence; however, we urge greater attention to the prioritization and sequencing of these interventions. See Michael ignatieff, Empire Lite: Nation Buildivg in Bosnia, Kosovo, and Afghanistan (2003); John Paul Lederach, Bulldinc Peace: Slustainable Reconciliation in Divided Societies (1998); Roland Paris, At War's End: Bullding Peace After Civil Confuict (2004). 
for democratic change can take place. However, we cannot assume that peace equals democracy. If an accurate assessment of opinion suggests that accountability should be second to state stability, then the international community might need to step back. This can be done with the awareness that transitional justice is a long-term process and that a state may only be adequately prepared years later to take on the challenge of adjudicating trials or exposing wrong-doing through a truth commission. The international emphasis on avoiding impunity as the highest priority may be ill advised. If we can accept the possibility that retributive justice may be delivered at a later time, justice delayed is not justice denied.

Finally, we cannot address these concerns without considering those who have been victimized by violence and repression. As we have learned, while many will prioritize holding perpetrators criminally accountable, this is not a universal finding either within a country or across countries and cultures. Similarly, survivors may find that truth-seeking mechanisms do not meet their needs for justice and reparations. We support the notion that victim-centered justice is critical, but we also suggest that it is not wise to make assumptions about who victims are and what justice is. Nor should we elevate the ideal of justice over alternative initiatives that may be best at a particular time for the people of the country as a whole. This is a delicate question and one that must be carefully assessed in context. Our analysis indicates vulnerabilities within each country that may influence the outcome of transitional justice and the complex interplay between the needs of victims and the needs of all who have survived is an area that desperately requires on-going study and evaluation.

Our findings suggest a need for new thinking about the relationship of justice to societal transitions. While these findings do not translate into tidy, operational guidelines, they do point to the need to reframe the current analytical framework through which transitional justice measures are promoted. The following statements emerge as principles to guide institutional development, scholarship, and policy prescriptions in the area of transitional justice:

There is a need for better modeling of dynamic social systems so that we can track developments in countries over time. In order to capture the benefits of adjusting the implementation, if not the design, of transitional justice mechanisms over time, policy makers and advocates need rigorous and comprehensive data to understand the evolution of the needs and priorities of individuals and communities and how attitudes are framed by broader political, legal, and social developments. Societal responses to transitional justice are informed by a host of factors and we need to be able to track these dynamic interactions.

Trials and truth commissions do not bring about the rule of law but are important symbols of the importance of and fealty to the rule of law; legiti- 
macy of domestic legal systems is critical to the success of transitional justice. Criminal prosecutions and truth commissions share symbolic celebration of rule of law principles but these institutions do not in and of themselves perform the work of building the rule of law culture and its supporting institutions. In instances where trials and truth commissions are instituted, it is important to capitalize on their potential to impact law reform more generally. This requires greater policy integration between these measures and rule of law initiatives.

Histories of external intervention impact transitional justice initiatives and need to be considered at all phases of the process. The paradox is that the need for the rule of law is greatest in countries in which colonialism and foreign intervention has been problematic, and these are countries in which transitional justice is likely to be implemented with international involvement. Diplomats, international legal professionals, scholars, and civil society that support internationally-sponsored transitional justice institutions need to anticipate and account for potential distortions that may surface in these contexts and their impact on implementation. Indigenous alternatives to foreign models of reckoning should be considered while guarding against their cooption by governmental agendas or reification of distorted local power relationships.

Sustained focus on the underlying causes of the conflict is essential so that trials and truth commissions do not become a fetish but an invitation for on-going attention to address the societal fissures. Political will to resolve these fractures may wane, be overcome by political backlash, or starved through lack of financial or technical support. The political appeal of the relatively narrow scope of transitional justice interventions should not divert attention to root causes. The role of international involvement in this area should vary depending on the context but be guided by the need to strengthen internal processes to address power imbalances without dictating their pace or outcome.

We offer these principles to suggest guideposts to develop, implement, and evaluate transitional justice mechanisms. A thicket of perils constrains a state's response to mass violence. There is no single set of "best practices," but rather, we suggest a set of considerations that move the field beyond moral exhortations to a more nuanced, proactive, and contextual framework. In this way, we can assure that transitional justice reflects more accurately the goals of its advocates with the recognition that humility and openness to innovation will be the best guarantors of social reconstruction. 